\title{
Optimization of Salt Marsh Management at the Chincoteague National Wildlife Refuge, Virginia, Through Use of Structured Decision Making
}

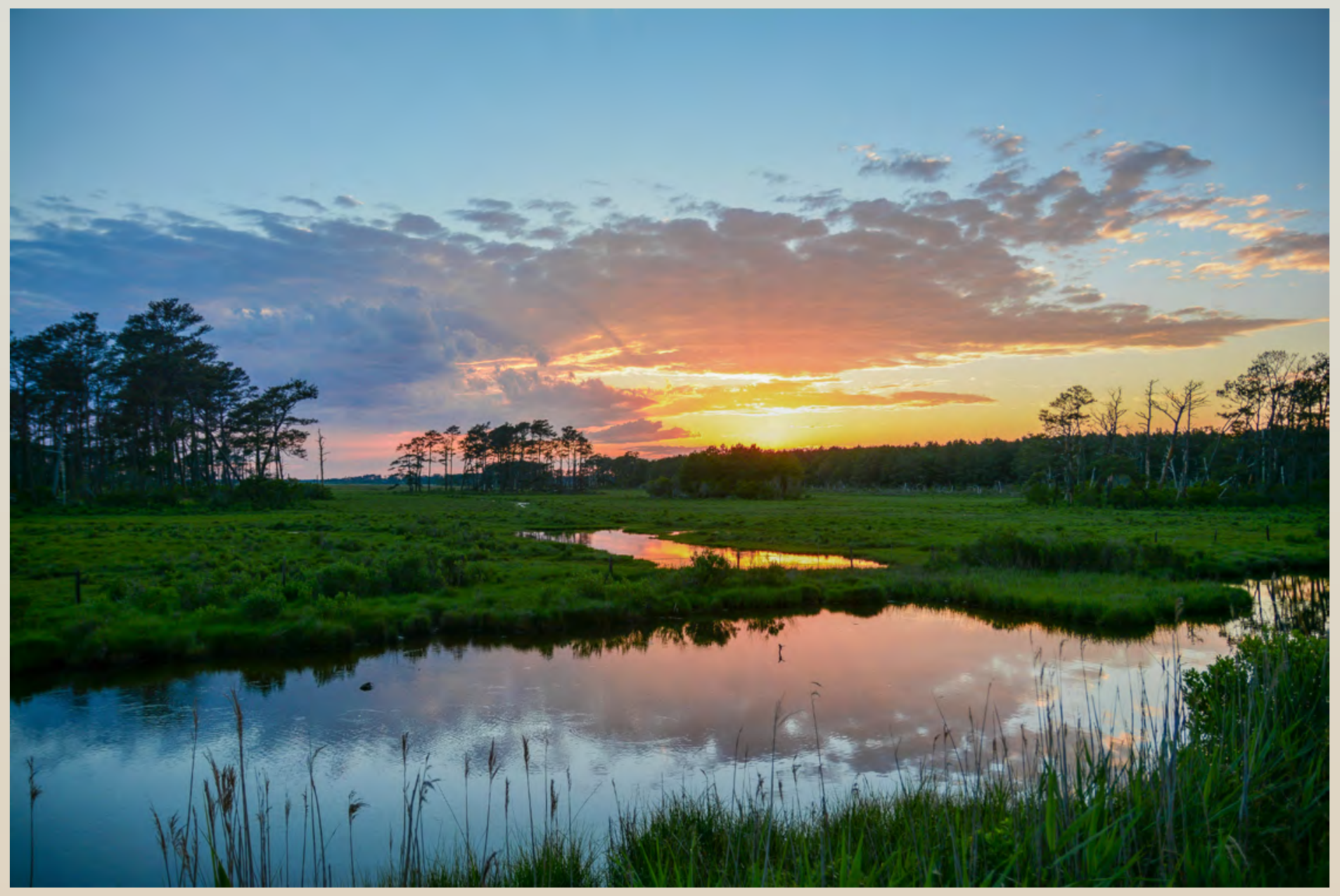

Open-File Report 2019-1056

U.S. Department of the Interior

U.S. Geological Survey 
Cover. Photograph of Black Duck Marsh at the Chincoteague National Wildlife Refuge in Virginia; photograph courtesy of Cole Kresch, used with permission by the U.S. Fish and Wildlife Service. 


\section{Optimization of Salt Marsh Management at the Chincoteague National Wildlife Refuge, Virginia, Through Use of Structured Decision Making}

By Hilary A. Neckles, James E. Lyons, Jessica L. Nagel, Susan C. Adamowicz, Toni Mikula, and Kevin S. Holcomb

Prepared in cooperation with the U.S. Fish and Wildlife Service

Open-File Report 2019-1056 


\title{
U.S. Department of the Interior DAVID BERNHARDT, Secretary
}

\author{
U.S. Geological Survey \\ James F. Reilly II, Director
}

U.S. Geological Survey, Reston, Virginia: 2019

For more information on the USGS - the Federal source for science about the Earth, its natural and living resources, natural hazards, and the environment-visit https://www.usgs.gov or call 1-888-ASK-USGS.

For an overview of USGS information products, including maps, imagery, and publications,

visit https://store.usgs.gov.

Any use of trade, firm, or product names is for descriptive purposes only and does not imply endorsement by the U.S. Government. The findings and conclusions in this article are those of the authors and do not necessarily represent the views of the U.S. Fish and Wildlife Service.

Although this information product, for the most part, is in the public domain, it also may contain copyrighted materials as noted in the text. Permission to reproduce copyrighted items must be secured from the copyright owner.

Suggested citation:

Neckles, H.A., Lyons, J.E., Nagel, J.L., Adamowicz, S.C., Mikula, T., and Holcomb, K.S., 2019, Optimization of salt marsh management at the Chincoteague National Wildlife Refuge, Virginia, through use of structured decision making: U.S. Geological Survey Open-File Report 2019-1056, 29 p., https://doi.org/10.3133/ofr20191056.

ISSN 2331-1258 (online) 


\section{Acknowledgments}

Virginia Rettig, Rich Albers, Paul Castelli, and Shane Daley of U.S. Fish and Wildlife Service (FWS) provided exceptional hospitality for the 2016 structured decision-making workshop at the Edwin B. Forsythe National Wildlife Refuge, New Jersey. Glenn Guntenspergen, landscape ecologist with U.S. Geological Survey (USGS), and Greg Shriver, avian ecologist with University of Delaware, generously contributed their time and expertise during the workshop; their history developing metrics to assess salt marsh integrity and their knowledge of salt marsh ecosystem dynamics were extremely helpful in applying the structured decision-making framework to the Chincoteague National Wildlife Refuge in Virginia. Nathan Bush of FWS generated the mapping data used in this report, and Jackie Olson of the USGS expertly prepared the maps. Technical reviews by Rachel Katz of the FWS and Bill Thompson of the National Park Service greatly improved the quality of this report. At the time of publication, data supporting this study have not been published by the U.S. Fish and Wildlife Service. 



\section{Contents}

Abstract

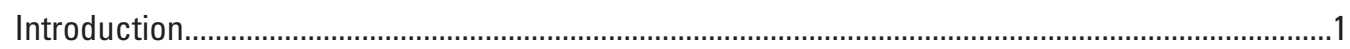

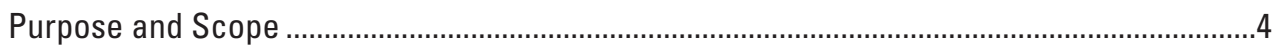

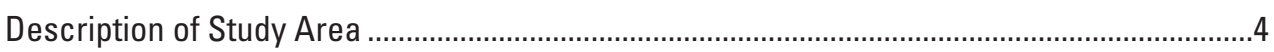

Regional Structured Decision-Making Framework ………..........................................................

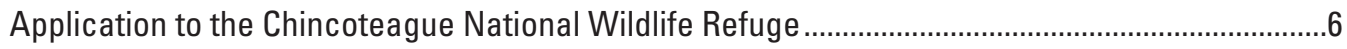

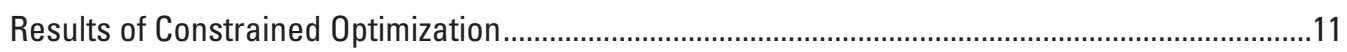

Considerations for Optimizing Salt Marsh Management..................................................................13

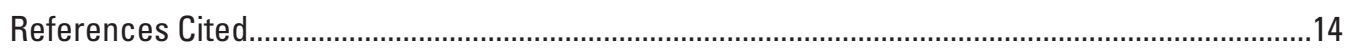

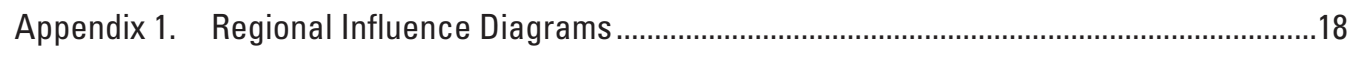

Appendix 2. Utility Functions for the Chincoteague National Wildlife Refuge..............................25

\section{Figures}

1. Map showing national wildlife refuges and national wildlife refuge complexes of the U.S. Fish and Wildlife Service where salt marsh integrity was assessed from 2012 to 2016 using the regional monitoring protocol ...................................................

2. Map showing salt marsh management units at the Chincoteague National Wildlife

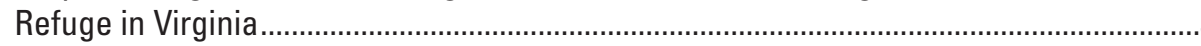

3. Graph showing predicted total management benefit of various portfolios, expressed as weighted utilities, relative to total annual cost at the Chincoteague National Wildlife Refuge in Virginia.

4. Graph showing predicted management benefit at the refuge scale for individual performance metrics, expressed as weighted utilities, resulting from implementation of the management actions included in portfolio 7, in comparison to the management benefit from the baseline "no-action" portfolio at the Chincoteague National Wildlife Refuge in Virginia......

\section{Tables}

1. Objectives hierarchy for salt marsh management decision problems.

2. Participants in workshop convened at the Edwin B. Forsythe National Wildlife Refuge, New Jersey, to apply a regional framework for optimizing salt marsh management decisions to five National Wildlife Refuges in November 2016

3. Possible management actions for achieving objectives within salt marsh management units at the Chincoteague National Wildlife Refuge, Virginia, estimated costs over 5 years, and predicted outcomes expressed relative to performance metrics..

4. Normalized predicted outcomes and estimated total management benefits of possible management actions within salt marsh management units at the Chincoteague National Wildlife Refuge in Virginia

5. Actions included in various management portfolios to maximize the total management benefits subject to increasing cost constraints in the Chincoteague National Refuge in Virginia 


\section{Conversion Factors}

International System of Units to U.S. customary units

\begin{tabular}{llc}
\hline Multiply & By & To obtain \\
\hline square meter $\left(\mathrm{m}^{2}\right)$ & 0.0002471 & acre \\
hectare (ha) & 2.471 & acre \\
\hline
\end{tabular}

\section{Datum}

Horizontal coordinate information is referenced to the North American Datum of 1983 (NAD 83). Elevation, as used in this report, refers to distance above the vertical datum.

\section{Abbreviations}

$\begin{array}{ll}\text { FWS } & \text { U.S. Fish and Wildlife Service } \\ \text { NWR } & \text { national wildlife refuge } \\ \text { NWRS } & \text { National Wildlife Refuge System } \\ \text { SMU } & \text { salt marsh unit } \\ \text { ppt } & \text { part per thousand } \\ \text { USGS } & \text { U.S. Geological Survey }\end{array}$




\title{
Optimization of Salt Marsh Management at the Chincoteague National Wildlife Refuge, Virginia, Through Use of Structured Decision Making
}

\author{
By Hilary A. Neckles, ${ }^{1}$ James E. Lyons, ${ }^{1}$ Jessica L. Nagel,, Susan C. Adamowicz, ${ }^{2}$ Toni Mikula, ${ }^{2}$ and \\ Kevin S. Holcomb²
}

\section{Abstract}

Structured decision making is a systematic, transparent process for improving the quality of complex decisions by identifying measurable management objectives and feasible management actions; predicting the potential consequences of management actions relative to the stated objectives; and selecting a course of action that maximizes the total benefit achieved and balances tradeoffs among objectives. The U.S. Geological Survey, in cooperation with the U.S. Fish and Wildlife Service, applied an existing, regional framework for structured decision making to develop a prototype tool for optimizing salt marsh management decisions at the Chincoteague National Wildlife Refuge in Virginia. Refuge biologists, refuge managers, and research scientists identified multiple potential management actions to improve the ecological integrity of 12 salt marsh management units within the refuge and estimated the outcomes of each action in terms of performance metrics associated with each management objective. Value functions previously developed at the regional level were used to transform metric scores to a common utility scale, and utilities were summed to produce a single score representing the total management benefit that would be accrued from each potential management action. Constrained optimization was used to identify the set of management actions, one per salt marsh management unit, that would maximize total management benefits at different cost constraints at the refuge scale. Results indicated that, for the objectives and actions considered here, total management benefits may increase consistently up to approximately $\$ 2.5$ million, but that further expenditures may yield diminishing return on investment. For multiple salt marsh management units, a scenario incorporating managing grazing practices within the marsh was selected to maximize benefits while constraining total costs for the refuge at less than $\$ 2.5$ million. Thin-layer deposition was predicted to increase the total management benefit substantially, but at

\footnotetext{
${ }^{1}$ U.S. Geological Survey.

${ }^{2}$ U.S. Fish and Wildlife Service.
}

considerable total costs ( $\$ 2.5$ million to $\$ 83$ million). The prototype presented here provides a framework for decision making at the Chincoteague National Wildlife Refuge that can be updated as new data and information become available. Insights from this process may also be useful to inform future habitat management planning at the refuge.

\section{Introduction}

The National Wildlife Refuge System (NWRS) protects extensive salt marsh acreage in the northeastern United States. Much of this habitat has been degraded by a succession of human activities since the time of European settlement (Gedan and others, 2009), and accelerated rates of sea-level rise exacerbate these effects (Gedan and others, 2011; Kirwan and Megonigal, 2013). Therefore, strategies to restore and enhance the ecological integrity of national wildlife refuge (NWR) salt marshes are regularly considered. Management may include such activities as reestablishing natural hydrology, augmenting or excavating sediments to restore marsh elevation, controlling invasive species, planting native vegetation, minimizing shoreline erosion, and remediating contaminant problems. Uncertainty stemming from incomplete knowledge of system status and imperfect understanding of ecosystem dynamics commonly hinders management predictions and consequent selection of the most effective management options. Consequently, tools for identifying appropriate assessment variables and evaluating tradeoffs among management objectives are valuable to inform marsh management decisions.

Structured decision making is a systematic approach to improving the quality of complex decisions that integrates assessment metrics into the decision process (Gregory and Keeney, 2002). This approach involves identifying measurable management objectives and potential management actions, predicting management outcomes, and evaluating tradeoffs to choose a preferred alternative. From 2008 to 2012, the U.S. Geological Survey (USGS) and U.S. Fish and Wildlife Service (FWS) used structured decision making to develop a framework for optimizing management 
decisions for NWR salt marshes in the FWS Northeast Region (that is, salt marshes in the coastal region from Maine through Virginia). The structured decision-making steps were applied through successive "rapid prototyping" workshops, an iterative process in which relatively short periods of time are invested to continually improve the decision structure (Blomquist and others, 2010; Garrard and others, 2017). The decision framework includes regional management objectives addressing critical components of salt marsh ecosystems, and associated performance metrics for determining whether objectives are achieved (Neckles and others, 2015). The regional objectives structure served as the foundation for a consistent protocol for monitoring salt marsh integrity at these northeastern coastal refuges, in which the monitoring variables are linked explicitly to management goals (Neckles and others, 2013). From 2012 to 2016, this protocol was used to conduct a baseline assessment of salt marsh integrity at all 17 refuges or refuge complexes in the FWS Northeast Region with salt marsh habitat (fig. 1).

The Chincoteague National Wildlife Refuge protects nearly 2,300 hectares (ha) of salt marsh, primarily on barrier islands off the eastern coast of the Delmarva Peninsula. The Wallops Island National Wildlife Refuge, which protects an additional 80 ha of salt marsh on the mainland, is managed as a satellite unit of Chincoteague National Wildlife Refuge and is included in the term "the refuge" in this report for descriptive and management purposes (fig. 2). The refuge's salt marsh provides critical nesting, migratory, and wintering

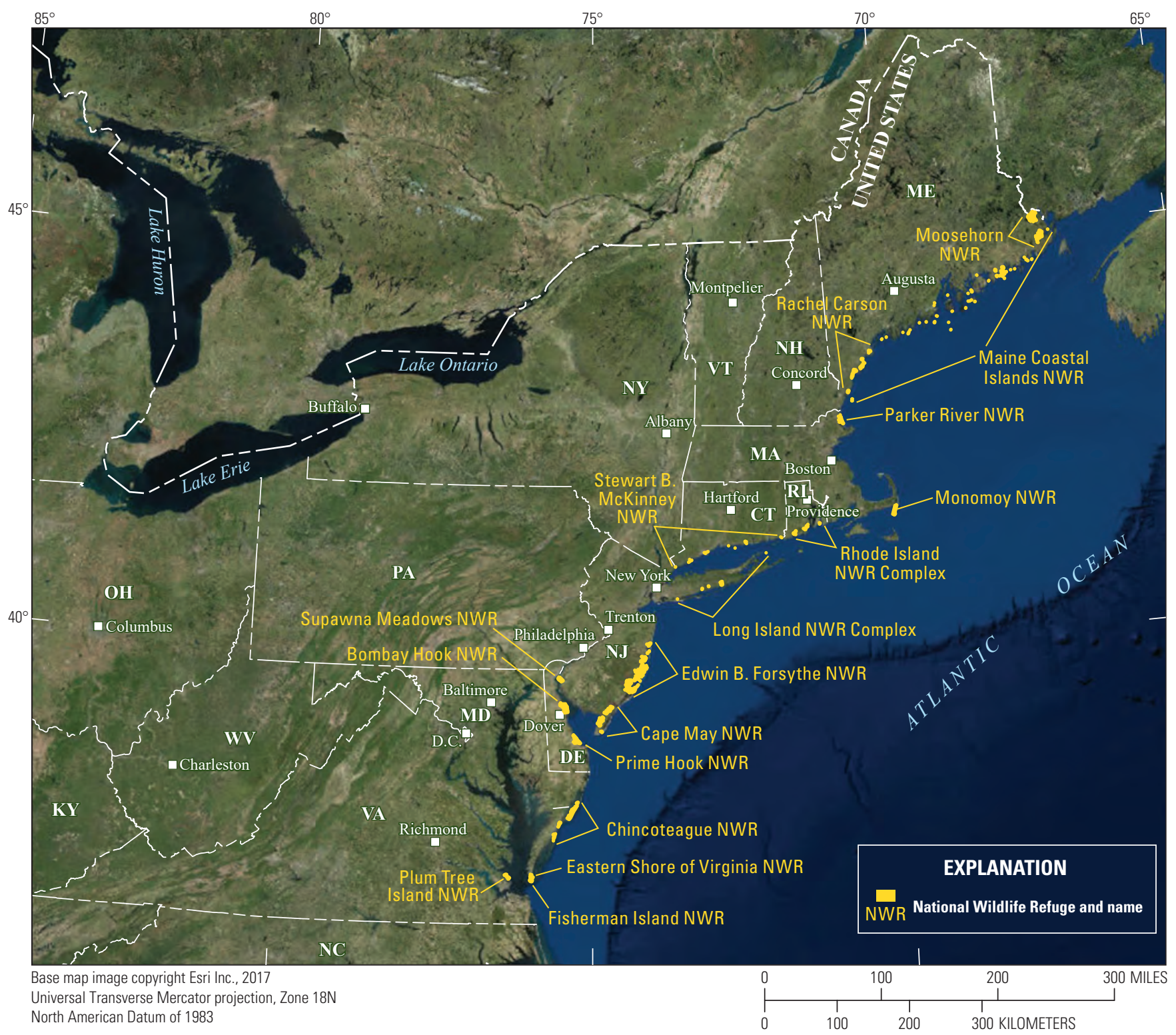

Figure 1. National wildlife refuges and national wildlife refuge complexes of the U.S. Fish and Wildlife Service where salt marsh integrity was assessed from 2012 to 2016 using the regional monitoring protocol. 


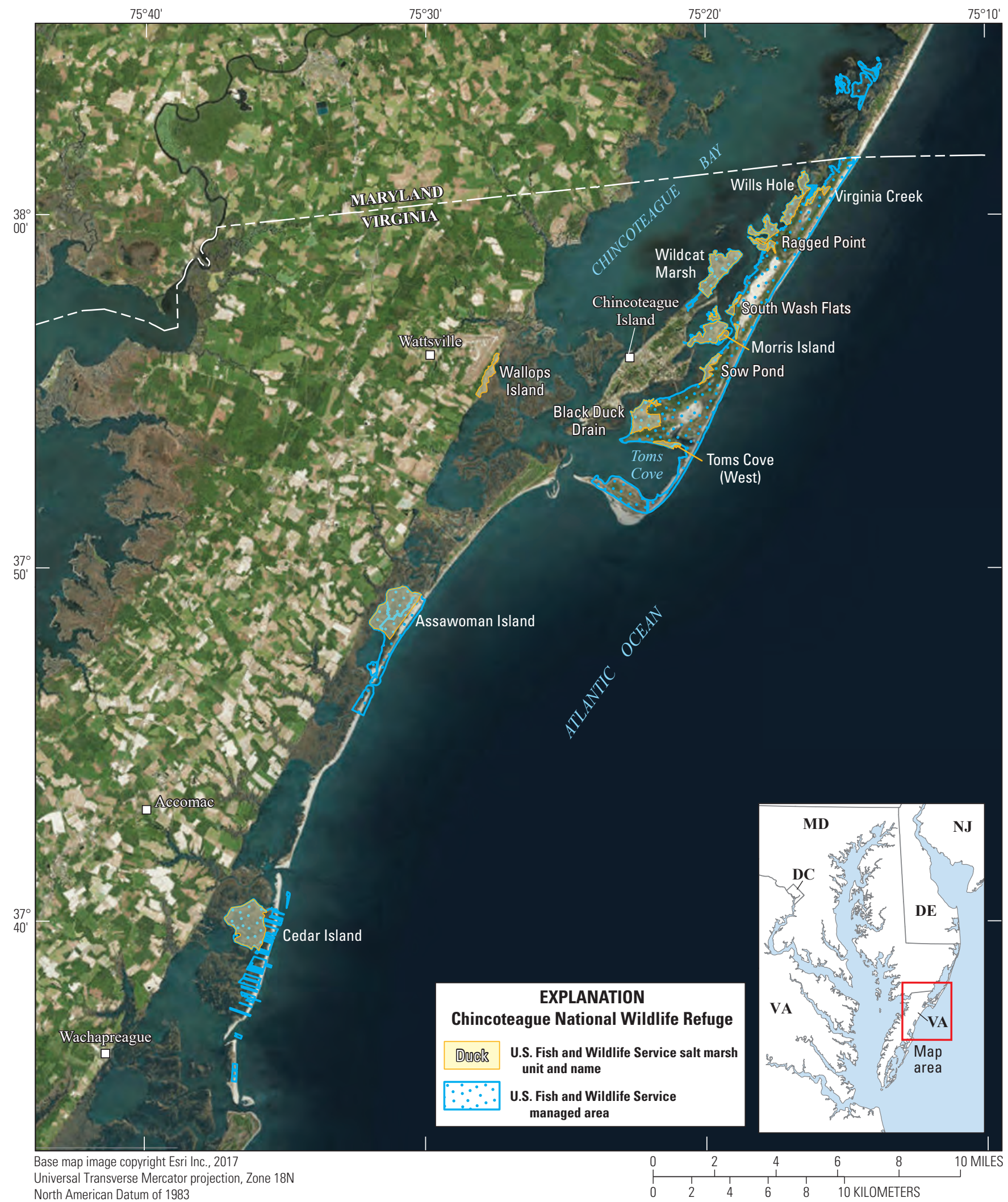

Figure 2. Salt marsh management units at the Chincoteague National Wildlife Refuge in Virginia. 
habitat for birds of highest conservation priority, including salt marsh sparrows, American oystercatchers, and American black ducks, in the U.S. North American Bird Conservation Initiative's Bird Conservation Region for the New England and mid-Atlantic coast (Steinkamp, 2008; FWS, 2015; Association of Fish and Wildlife Agencies, 2019). The primary threat to this habitat is submergence from rising sea level (FWS, 2015). In addition, grazing by Chincoteague ponies, small feral horses found on Assateague Island, can alter marsh vegetation structure, which results in habitat loss for nesting, migrating, and wintering birds that are among the refuge's focal management species. Salt marsh management goals for the refuge focus on maintaining high-quality habitat for breeding, migrating, and wintering birds by adjusting the amount of salt marsh accessible for pony grazing and restoring and enhancing habitat. Therefore, in this study, the regional structured decision-making framework was used to help prioritize salt marsh management options for the refuge.

\section{Purpose and Scope}

This report describes the application of the regional structured decision-making framework (Neckles and others, 2015) to the Chincoteague National Wildlife Refuge. The regional framework was parameterized to local conditions through rapid prototyping, producing a decision model for the refuge that can be updated as new information becomes available. Included are a suite of potential management actions to achieve objectives in 12 salt marsh management units at the refuge (fig. 2), approximate costs for implementing each potential action, predictions for the outcome of each management action relative to individual management objectives, and results of constrained optimization to maximize management benefits subject to cost constraints. This decision structure can be used to understand how specific actions may contribute to achieving management objectives and identify an optimum combination of actions, or "management portfolio," to maximize management benefits at the refuge scale for a range of potential budgets. The prototype presented here provides a framework for continually improving the quality of complex management decisions at the Chincoteague National Wildlife Refuge.

\section{Description of Study Area}

The Chincoteague National Wildlife Refuge is a coastal barrier island and lagoonal system that encompasses beaches and dunes, maritime forests, and back barrier marshes. The salt marsh is divided into 12 management units (referred to as salt marsh units): Virginia Creek, Wills Hole, Ragged Point, Wildcat Marsh, South Wash Flats, Morris Island, Sow Pond, Toms Cove (West), Black Duck Drain, Wallops Island, Assawoman Island, and Cedar Island (fig. 2). More than 50 percent of the perimeter of each salt marsh unit is bordered by open water, resulting in a strong influence of tidal hydrology on the marshes. From 2012 to 2016, average surface-water salinities in the summer ranged from about 27 to 36 parts per thousand (ppt) within the barrier island salt marshes, making the surface water polyhaline to euhaline (as defined by Cowardin and others, 1979), and was about $14 \mathrm{ppt}$ at Wallops Island (S.C. Adamowicz and T. Mikula, FWS, unpub. data, 2017), making the water mesohaline (as defined by Cowardin and others, 1979). The salt marshes throughout the refuge are relatively unaltered by direct human activities and are surrounded by natural land uses classified as other than agricultural or developed categories within the 2011 National Land Cover Database (U.S. Geological Survey, 2014; S.C. Adamowicz and T. Mikula, FWS, unpub. data, 2017). The predominant upland habitat is loblolly pine and loblolly pine and hardwoods maritime forest (FWS, 2015). Chincoteague ponies graze throughout 40 percent of the Assateague Island part of the refuge under a special use permit to the Chincoteague Volunteer Fire Company, and much of the grazed area is salt marsh (FWS, 2015). The invasive plant Phragmites australis has been documented in only three salt marsh units (Sow Pond, Wallops Island, and Wills Hole) where it occurs in low densities (S.C. Adamowicz and T. Mikula, FWS, unpub. data, 2017).

\section{Regional Structured Decision-Making Framework}

A regional framework for assessing and managing salt marsh integrity at northeastern NWRs was developed through collaborative efforts of FWS regional and refuge managers and biologists, salt marsh research scientists, and structured decision-making experts. This process followed the discrete steps outlined by Hammond and others (1999) and Gregory and Keeney (2002):

1. Clarify the temporal and spatial scope of the management decision.

2. Define objectives and performance measures to evaluate whether objectives are achieved.

3. Develop alternative management actions for achieving objectives.

4. Estimate the consequences or likely outcomes of management actions in terms of the performance measures.

5. Evaluate the tradeoffs inherent in potential alternatives and select the optimum alternatives to maximize management benefits.

This sequence of steps was applied through successive workshops to refine the decision structure and incorporate newly available information. Initial development of the structured decision-making framework occurred during a weeklong workshop in 2008 to define the decision problem, specify management objectives, and explore strategies available to 
restore and enhance salt marsh integrity. During 2008 and 2009, workshop results were used to guide field tests of salt marsh monitoring variables (Neckles and others, 2013). Subsequently, in 2012, data and insights gained from these field tests were used in a two-part workshop to refine management objectives and develop the means for evaluating management outcomes (Neckles and others, 2015).

From the outset, FWS goals included development of an approach for consistent assessment of salt marsh integrity across all northeastern NWRs (fig. 1). Within this regional context, staff at a given refuge must periodically determine the best approaches for managing salt marshes to maximize habitat value while considering financial and other constraints. The salt marsh decision problem was thus defined as applying to individual NWRs over a 5-year planning horizon. The objectives for complex decisions can be organized into a hierarchy to help clarify what is most important to decision makers (Gregory and others, 2012). The hierarchy of objectives for salt marsh management decisions (table 1) was based explicitly on the conservation mission of the NWRS, which is upheld through management to "ensure that the biological integrity, diversity, and environmental health of the System are maintained for the benefit of present and future generations of Americans," as mandated in the National Wildlife Refuge System Improvement Act of 1997 (16 U.S.C. 668dd note). Two fundamental objectives, or the overall goals for salt marsh management decisions, were drawn from this policy to maximize (1) biological integrity and diversity and (2) environmental health, of salt marsh ecosystems. Participants in the prototyping workshops deconstructed these overall goals into low-level objectives relating to salt marsh structure and function and identified performance metrics to evaluate whether objectives are achieved (table 1). In addition, performance metrics were weighted to reflect the relative importance of each objective (Neckles and others, 2015).

The hierarchy of objectives for salt marsh management (table 1) provides the foundation for identifying possible management actions at individual NWRs and predicting management outcomes. Workshop participants developed preliminary influence diagrams (app. 1), or conceptual models relating

Table 1. Objectives hierarchy for salt marsh management decision problems.

[Two fundamental objectives (overall goals of the decision problem) draw directly from National Wildlife Refuge System policy to maintain, restore, and enhance biological integrity, diversity, and environmental health within the refuge. These objectives are broken down into low-level objectives focused on specific aspects of marsh structure and function. Values in parentheses are weights assigned to objectives, reflecting their relative importance. Weights on any branch of the hierarchy sum to 1 . The weight for each metric is the product of the weights from each level of the hierarchy leading to that metric. NA, not applicable]

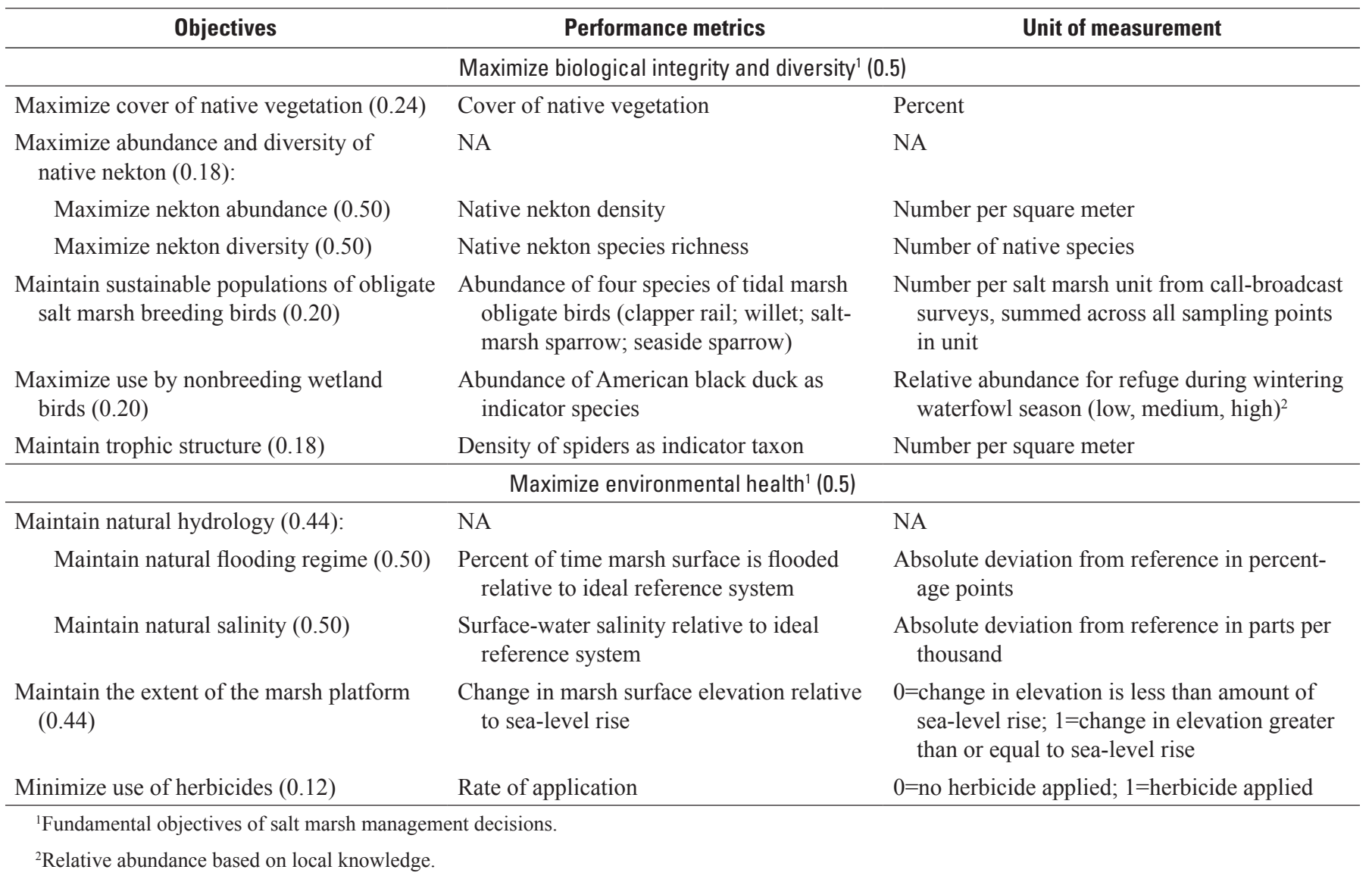


management actions to responses by each performance metric (Conroy and Peterson, 2013), to guide this process. To allow metric responses to be aggregated into a single, overall performance score, participants also defined value functions relating salt marsh integrity metric scores to perceived management benefit on a common, unitless "utility" scale (Keeney and Raiffa, 1993). Stakeholder elicitation was used to determine the form of each value function relating the original metric scale to the utility scale, ranging from 0 , representing the lowest management benefit, to 1 , representing the highest benefit (app. 2). Neckles and others (2015) provided details regarding development of the structured decision-making framework and a case-study application to Prime Hook National Wildlife Refuge.

\section{Application to the Chincoteague National Wildlife Refuge}

In November 2016, FWS regional biologists, biologists and managers from six northeastern NWR administrative units, and USGS and University of Delaware research scientists (table 2) participated in a 1.5-day rapid-prototyping workshop to apply the regional structured decision-making framework to the Chincoteague, Bombay Hook, Cape May, Supawna Meadows, and Forsythe National Wildlife Refuges and the Rhode Island National Wildlife Refuge Complex. Participants worked within refuge-specific small groups to focus on management issues at individual refuges. Plenary discussions of common patterns of salt marsh degradation, potential management strategies, and mechanisms of ecosystem response offered additional insights to enhance refuge-specific discussions.

Participants identified a range of possible management actions for achieving objectives within each salt marsh unit at the Chincoteague National Wildlife Refuge and estimated the total cost of implementation over 5 years. Potential actions to enhance salt marsh integrity ranged from evaluating grazing practices for improving habitat quality in focused locations to large-scale projects for altering marsh elevation (table 3). Invasive species occurred at low densities in only three salt marsh units and were predicted to have minimal influence on marsh vegetation; therefore, invasive control strategies were not considered in this prototype. Participants predicted the outcomes of each management action 5 years after implementation in terms of salt marsh integrity performance metrics. For most metrics, baseline conditions within each unit measured during the 2012-16 salt marsh integrity assessment (S.C. Adamowicz and T. Mikula, FWS, unpub. data, 2017) were used to predict the outcomes of a "no-action" alternative. Baseline conditions were estimated by using expert judgement for three metrics that lacked assessment data (abundance of American black ducks, density of spiders, change in marsh surface elevation relative to sea-level rise). Regional influence diagrams relating management strategies to outcomes
Table 2. Participants in workshop convened at the Edwin B. Forsythe National Wildlife Refuge, New Jersey, to apply a regional framework for optimizing salt marsh management decisions to five National Wildlife Refuges in November 2016.

[FWS, U.S. Fish and Wildlife Service; NWR, National Wildlife Refuge; USGS, U.S. Geological Survey]

\begin{tabular}{|c|c|}
\hline Affiliation & Participant \\
\hline \multicolumn{2}{|l|}{ FWS NWR specialists } \\
\hline Bombay Hook NWR & Susan Guiteras \\
\hline $\begin{array}{l}\text { Cape May NWR and Supawna Meadows } \\
\text { NWR }\end{array}$ & Brian Braudis \\
\hline $\begin{array}{l}\text { Cape May NWR and Supawna Meadows } \\
\text { NWR }\end{array}$ & Heidi Hanlon \\
\hline $\begin{array}{l}\text { Cape May NWR and Supawna Meadows } \\
\text { NWR }\end{array}$ & Victor Nage \\
\hline $\begin{array}{l}\text { Cape May NWR and Supawna Meadows } \\
\text { NWR }\end{array}$ & Jack Szczepanski \\
\hline Chincoteague NWR & Kevin Holcomb \\
\hline Chincoteague NWR & Jennifer Miller \\
\hline Edwin B. Forsythe NWR & Paul Castelli \\
\hline Edwin B. Forsythe NWR & Virginia Rettig \\
\hline Rhode Island NWR Complex & Nick Ernst \\
\hline Rhode Island NWR Complex & Charlie Vandemoer \\
\hline \multicolumn{2}{|c|}{ FWS regional experts } \\
\hline Northeast Regional Office & Laura Mitchell \\
\hline Rachel Carson NWR & Susan Adamowicz \\
\hline Rachel Carson NWR & Toni Mikula \\
\hline \multicolumn{2}{|l|}{ Research scientists } \\
\hline University of Delaware & W. Gregory Shriver \\
\hline USGS Patuxent Wildlife Research Center & Glenn Guntenspergen \\
\hline USGS Patuxent Wildlife Research Center & James Lyons \\
\hline USGS Patuxent Wildlife Research Center & Hilary Neckles \\
\hline
\end{tabular}

aided in predicting consequences of management actions (app. 1). Although the influence diagrams incorporated the potential effects of stochastic processes, including weather, sea-level rise, herbivory, contaminant inputs, and disease, on management outcomes, no attempt was made to quantify these sources of uncertainty during rapid prototyping. Management predictions also inherently included considerable uncertainty surrounding the complex interactions among controlling factors and salt marsh ecosystem components.

Following the workshop, the potential management benefit of each salt marsh integrity performance metric was calculated by converting salt marsh integrity metric scores (table 3, workshop output) to weighted utilities (table 4), using regional value functions (app. 2). Weighted utilities were summed across all salt marsh integrity metrics for each action; this overall utility therefore represented the total management 


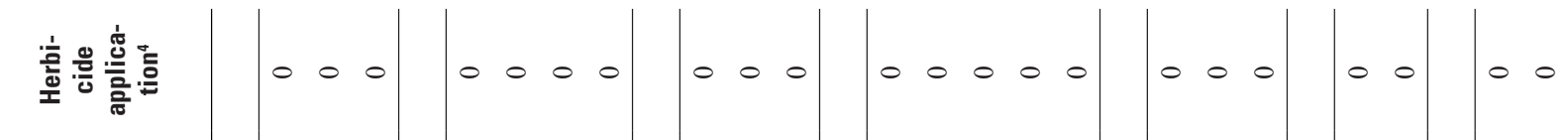

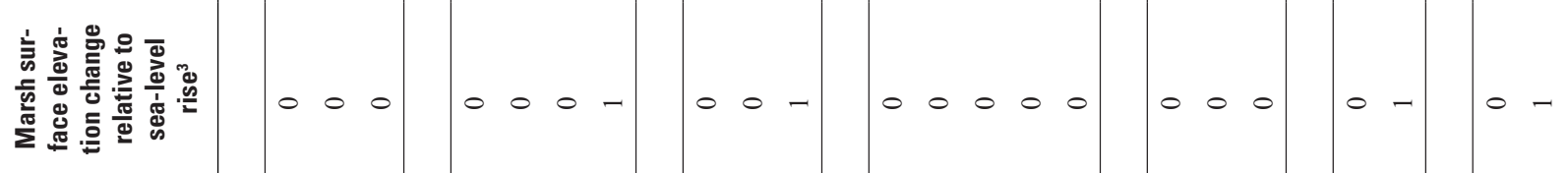

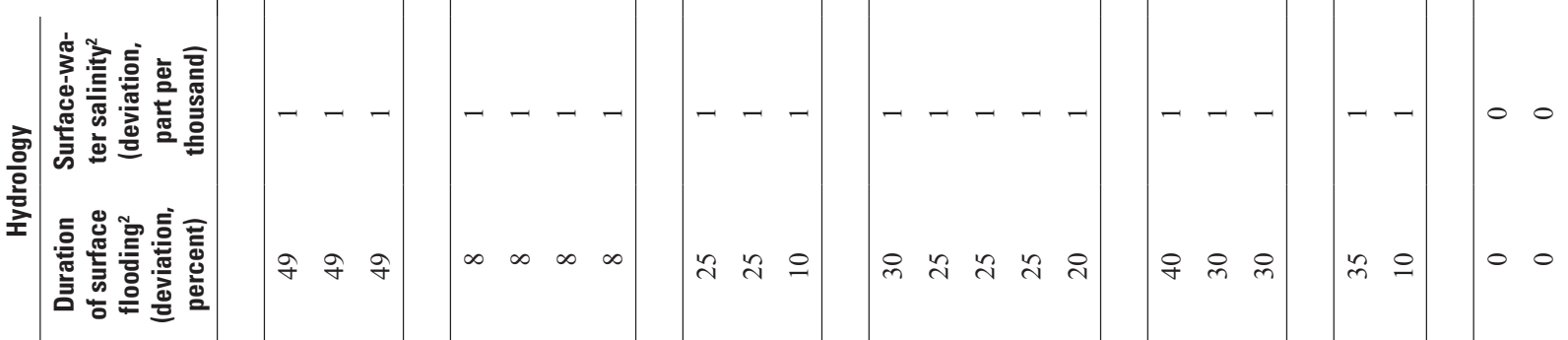

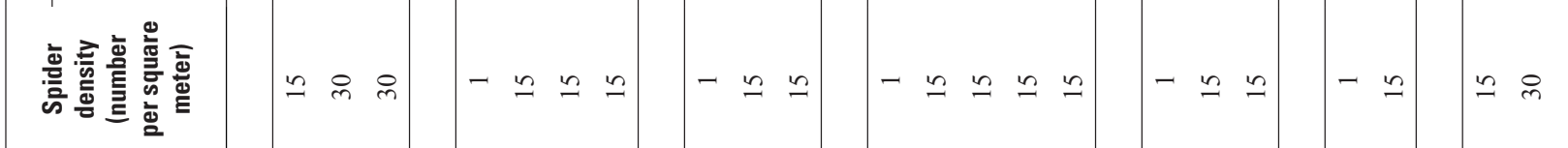

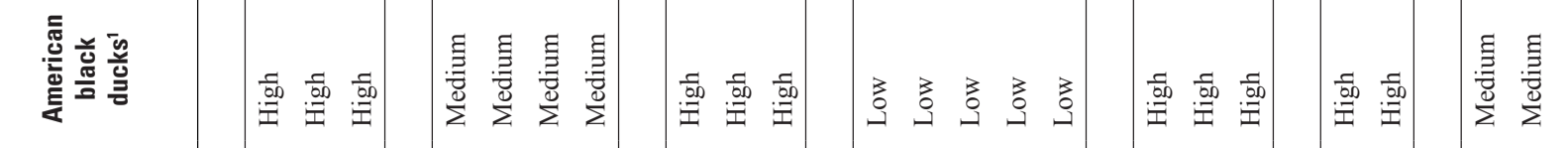
$\stackrel{\oplus}{\rightleftarrows}$

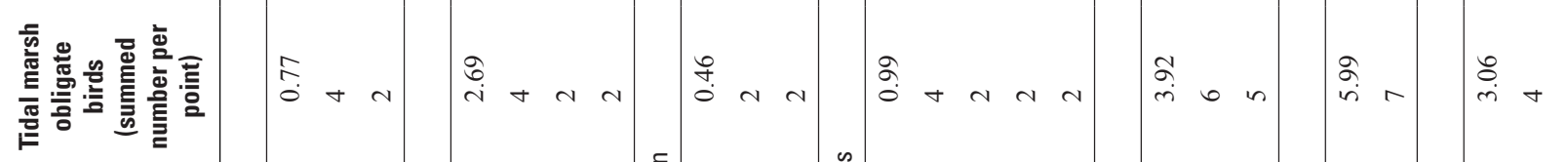

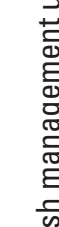

$$
\text { 彭哀 }
$$

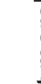

政 毫

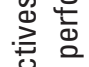
$\stackrel{\oplus}{2}$

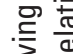
$\frac{0}{\frac{1}{0}}$ \% 웅 x 음 \& 号 흠 웅 는 흘 焉 : $\frac{2}{2}$ ल $\stackrel{0}{2}$ 这

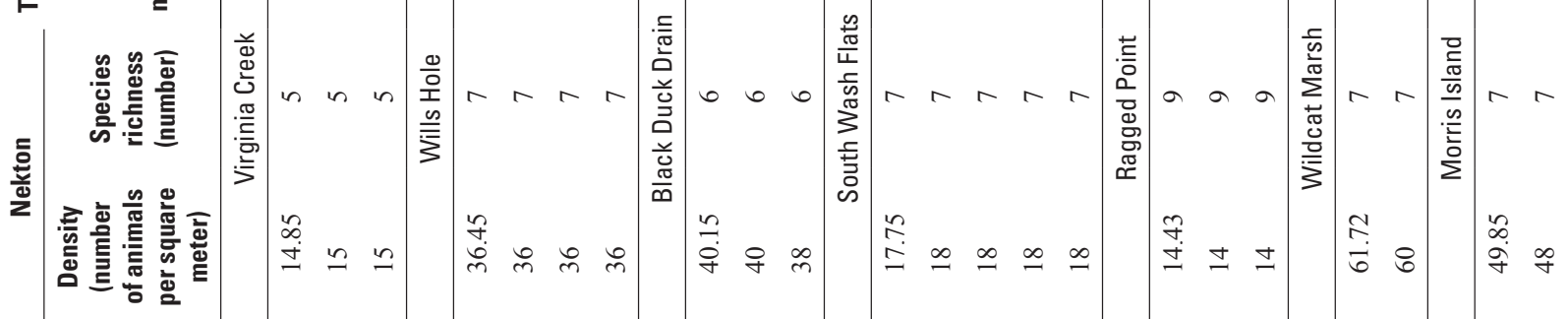

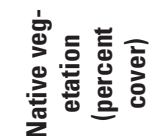

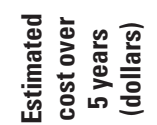

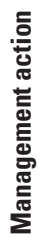

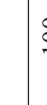

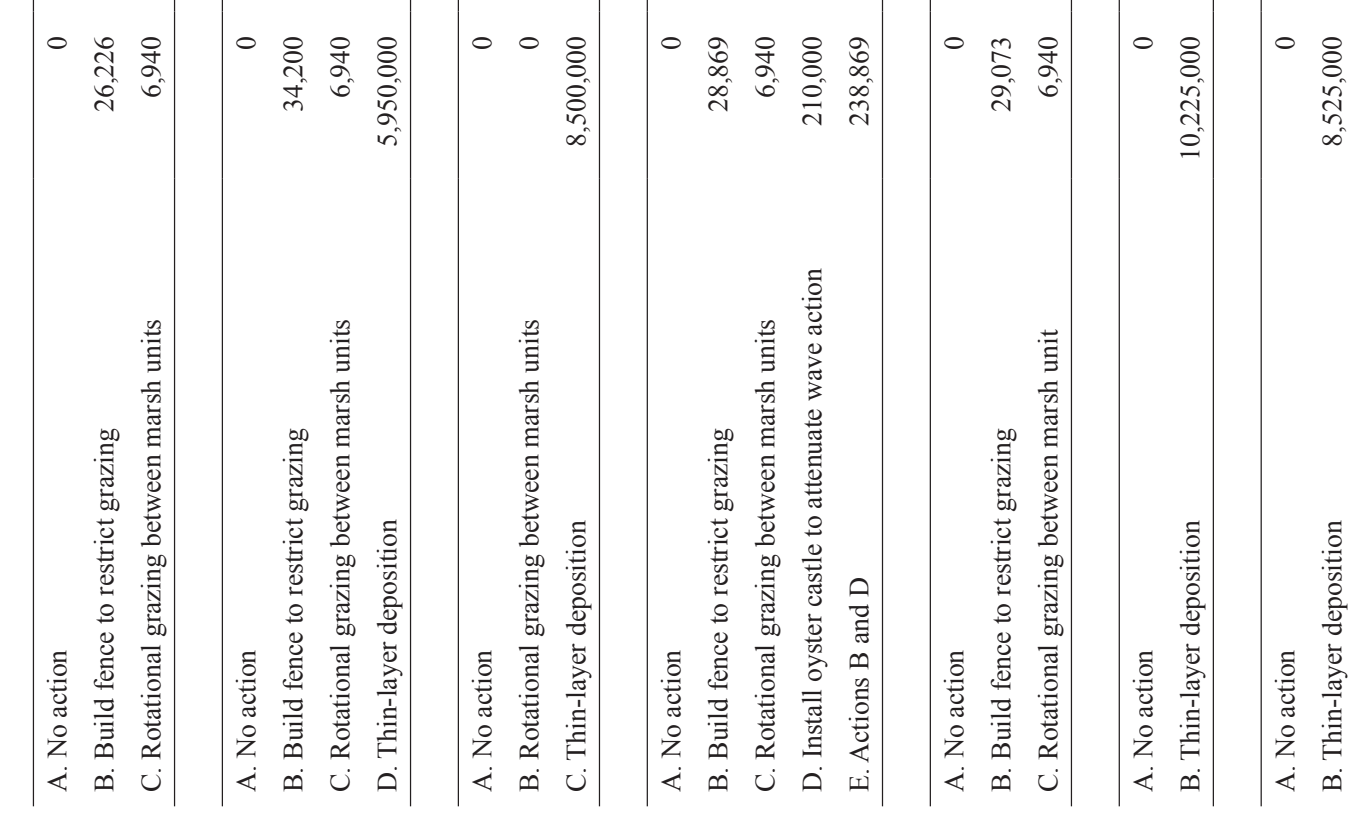




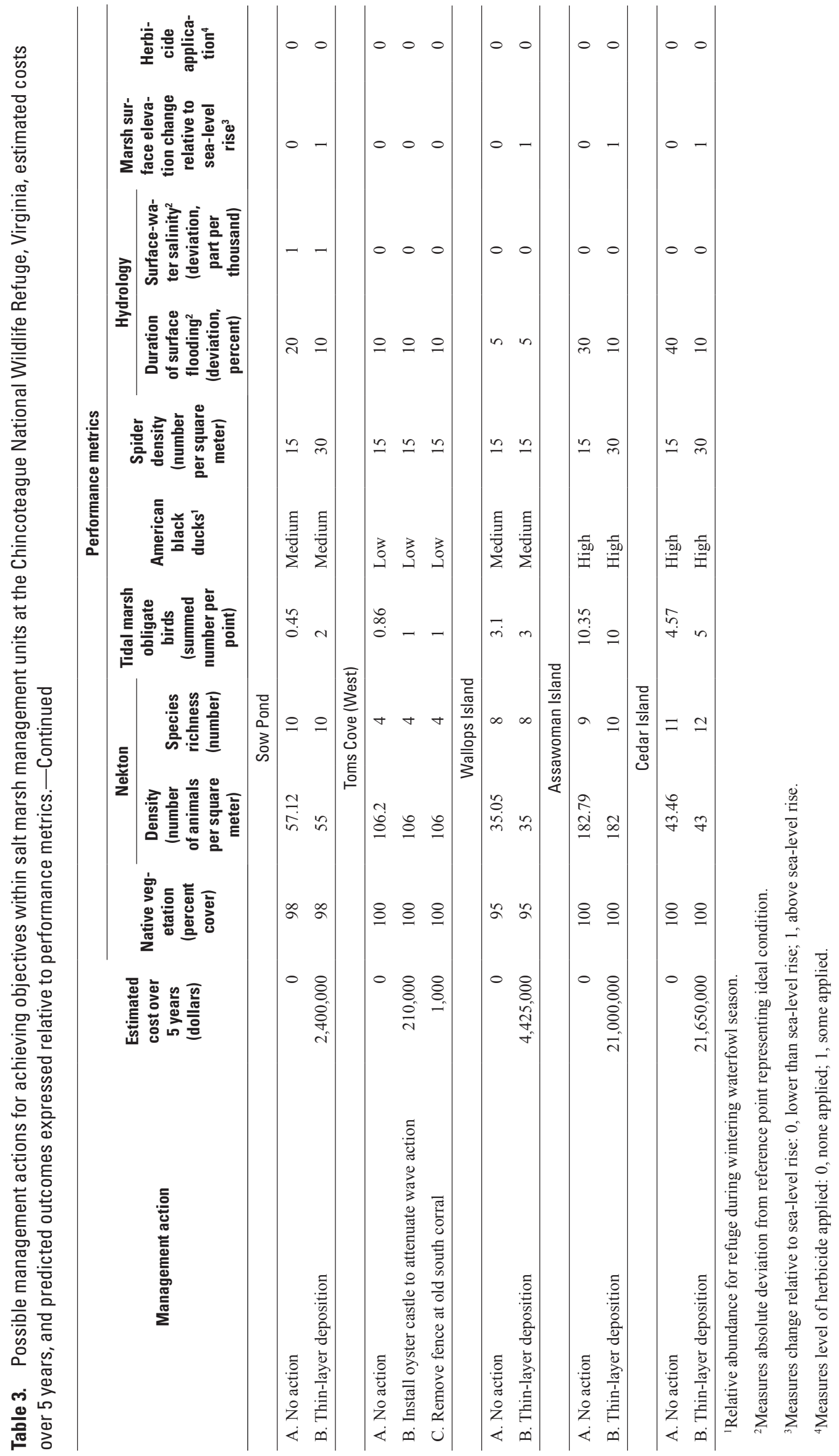




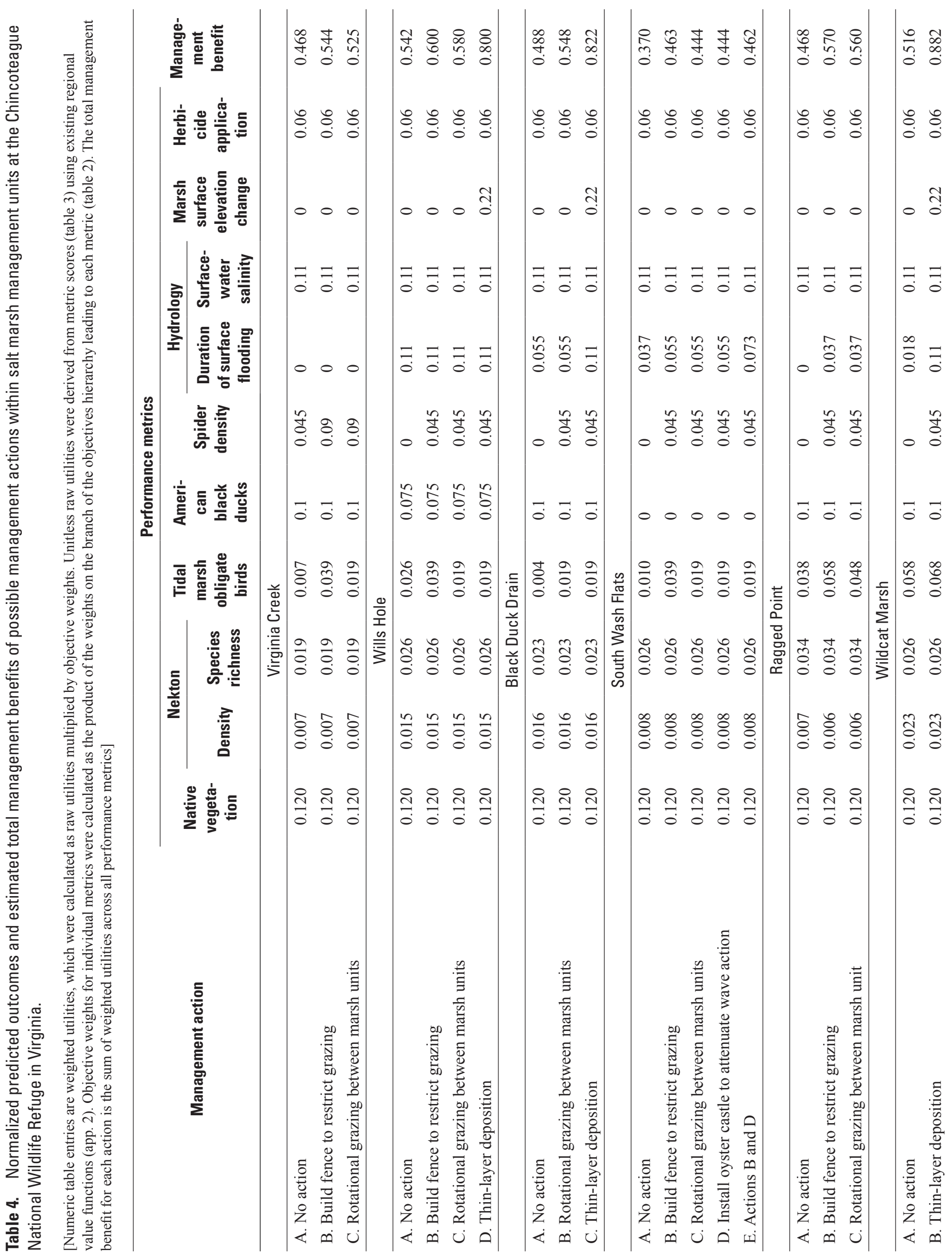




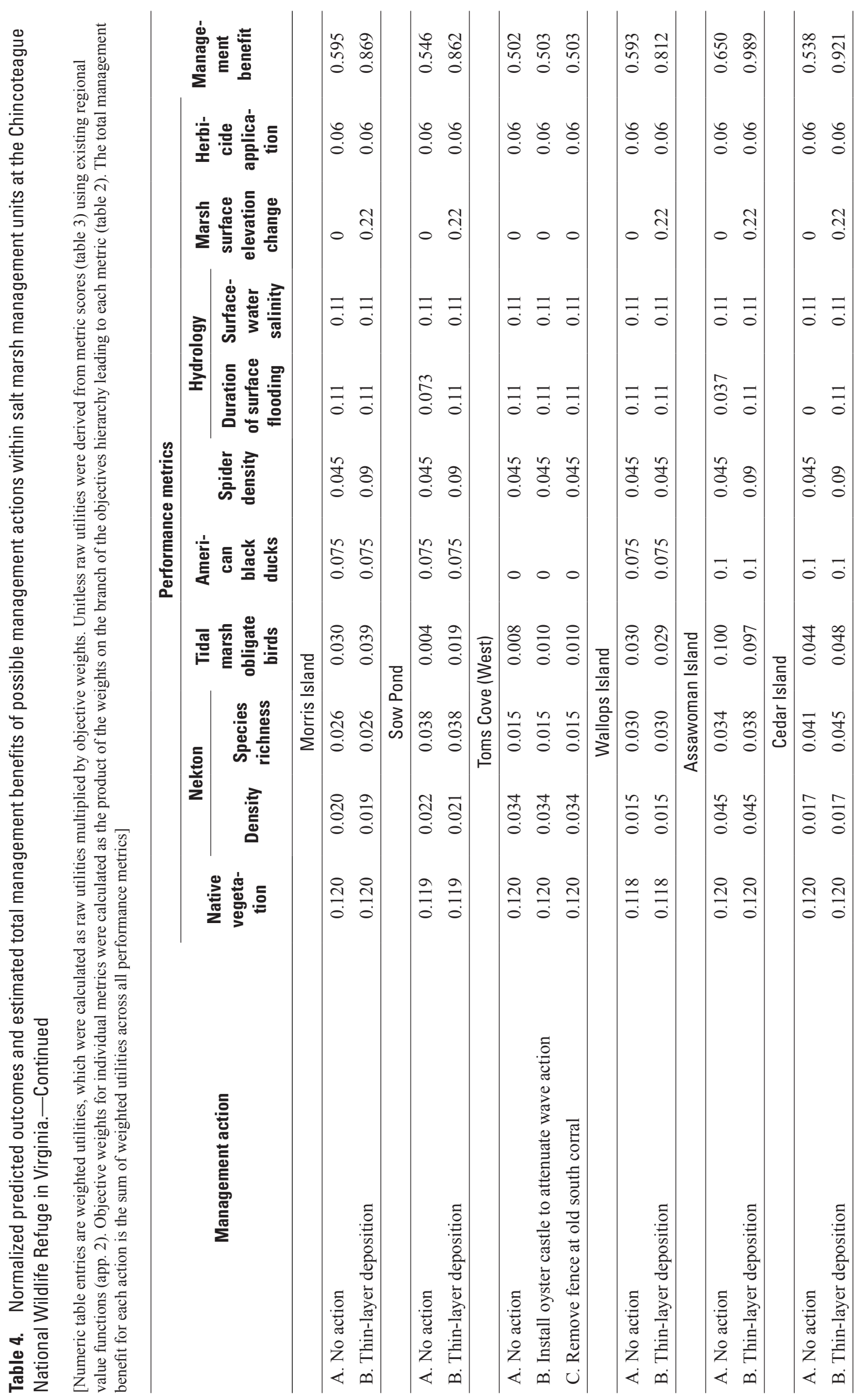


benefit, across all objectives, expected to accrue from a given management action (table 4). Constrained optimization (Conroy and Peterson, 2013) was used to find the management portfolio (the combination of actions, one action per salt marsh unit), that maximizes the total management benefit across all units under varying cost scenarios for the entire the refuge. Constrained optimization using integer linear programming was implemented in the Solver tool in Microsoft Excel (Kirkwood, 1997). Budget constraints were increased in $\$ 10,000$ increments up to $\$ 50,000$; in $\$ 50,000$ increments up to $\$ 300,000$; in $\$ 100,000$ increments up to $\$ 1$ million; in $\$ 2.5$ million increments up to $\$ 10$ million; and in $\$ 5$ million to $\$ 10$ million increments thereafter. A cost-benefit plot of the portfolios identified through the optimization analysis was used to identify the efficient frontier for resource allocation (Keeney and Raiffa, 1993), which is the set of portfolios that are not dominated by other portfolios at similar costs (or the set of portfolios with maximum total benefit for a similar cost). The cost-benefit plot also revealed the cost above which further expenditures would yield diminishing returns on investment. To exemplify use of the decision-making framework to understand how a given portfolio could affect specific management objectives, the refuge-scale management benefits for individual performance metrics were compared between one optimal portfolio and those predicted with no management action taken.

\section{Results of Constrained Optimization}

Management actions identified to improve salt marsh integrity at the Chincoteague National Wildlife Refuge included strategies to manage grazing of marsh vegetation by Chincoteague ponies, to restore or enhance physical marsh features, and to protect shorelines from erosion (table 3). Within individual salt marsh units, for costs ranging from $\$ 0$ to $\$ 21.65$ million, the estimated management benefits for specific actions across all metrics (measured as weighted utilities) ranged from 0.370 to 0.989 (tables 3 and 4). Within each unit, the action with both the lowest management benefit and lowest cost was the "no-action" option (action A).

Constrained optimization was applied to identify the optimal management portfolios over 5 years for a range of total costs to the refuge. As total cost increased from $\$ 0$ (no action in any unit) to approximately $\$ 82$ million, the total management benefit at the refuge scale increased by 43 percent, from 6.337 to 9.037 (table 5) out of a possible maximum of 12.0 (the maximum possible management benefit of 1.0 for any management action, summed across 12 salt marsh units). Graphical analysis showed a fairly consistent increase in management benefit as costs increased to $\$ 2.5$ million (fig. 3 , portfolio 7). As expenditures increased beyond the cost of portfolio 7, total management benefit continued to increase but at a lower rate, yielding diminishing returns on investment.
Several patterns emerged relative to management actions selected for yielding the best returns on investments within the optimal set of portfolios with a cost of less than $\$ 2.5$ million (portfolios 2 through 7; table 5). For the five Assateague Island salt marsh units where marsh disturbance by ponies was a primary management concern (Virginia Creek, Wills Hole, Black Duck Drain, South Wash Flats, and Ragged Point), optimal portfolios consistently included actions to manage grazing. At Toms Cove (West), the low-cost action of removing dilapidated fencing at the old south pony corral was consistently part of the optimized portfolios. At Sow Pond Marsh, taking no action was consistently selected for portfolios with total costs less than $\$ 120,000$ (portfolios 2 through 6); when cost constraints were increased to $\$ 2.497$ million, the optimal portfolio included performing thin-layer deposition in this unit (portfolio 7). At five units (Wildcat Marsh, Morris Island, Wallops Island, Assawoman Island, and Cedar Island), the cost of thin-layer deposition excluded this action from portfolios until total expenditures were very high ( $\$ 4.4$ million to $\$ 21.65$ million); thus, "no action" was consistently included within the lower cost portfolios. Although installing oyster castles to attenuate wave action was identified as an action to reduce erosion of marsh edges within two units (South Wash Flats and Toms Cove [West]), this action was never selected in any portfolios for South Wash Flats and was selected for Toms Cove by only two portfolios, both of which had total costs beyond the point of diminishing returns (portfolios 8 and 10).

Examination of the refuge-scale metric responses to actions included in portfolio 7, which is the turning point in the cost-benefit plot (fig. 3), revealed how implementation would affect specific management objectives. The actions included in portfolio 7 generated a prediction of modest gains in the overall management benefits derived from changes to the numbers of tidal marsh obligate birds and spiders (as an indicator of trophic health), flooding duration, and marsh surface elevation change (fig. 4). Ecologically, the combination of actions in this portfolio may result in an average 480 percent increase in spider density (averaged across all units), 125 percent increase in tidal marsh obligate bird counts, 8 percent decrease in the deviation of surface flooding from the ideal reference condition, and an increased capacity for marsh elevation to keep pace with sea level rise in 1 of the 12 salt marsh units (derived as the average difference between the predicted metric scores for the actions implemented in portfolio 7 and the "no-action" alternative; table 3 ). The management benefits predicted for portfolios 2 through 6 , at total costs substantially lower than portfolio 7 , were derived primarily from expected increases in spider density and tidal marsh obligate birds in response to grazing management (within the Virginia Creek, Wills Hole, Black Duck Drain, South Wash Flats, Ragged Point, and Toms Cove [West] units; tables 3 and 4). 
Table 5. Actions included in various management portfolios to maximize the total management benefits subject to increasing cost constraints in the Chincoteague National Refuge in Virginia.

[Letter designations for actions refer to specific actions and are listed in tables 3 and 4. Portfolios represent the combination of actions, one per salt marsh unit, that maximized the total management benefit across all units subject to a refuge-wide cost constraint. The management actions constituting individual portfolios were selected using constrained optimization. The maximum possible total management benefit for the refuge is 12 , derived as the maximum possible total management benefit of 1.0 for any management action within one management unit, summed across 12 units]

\begin{tabular}{|c|c|c|c|c|c|c|c|c|c|c|c|c|c|c|}
\hline \multirow[b]{2}{*}{$\begin{array}{l}\text { Portfo- } \\
\text { lio }\end{array}$} & \multicolumn{12}{|c|}{ Salt marsh management unit } & \multirow[b]{2}{*}{$\begin{array}{l}\text { Total cost } \\
\text { (dollars) }\end{array}$} & \multirow[b]{2}{*}{$\begin{array}{c}\text { Total } \\
\text { manage- } \\
\text { ment } \\
\text { benefit }\end{array}$} \\
\hline & $\begin{array}{c}\text { Vir- } \\
\text { ginia } \\
\text { Creek }\end{array}$ & $\begin{array}{l}\text { Wills } \\
\text { Hole }\end{array}$ & $\begin{array}{l}\text { Black } \\
\text { Duck } \\
\text { Drain }\end{array}$ & $\begin{array}{l}\text { South } \\
\text { Wash } \\
\text { Flats }\end{array}$ & $\begin{array}{c}\text { Ragged } \\
\text { Point }\end{array}$ & $\begin{array}{l}\text { Wild- } \\
\text { cat } \\
\text { Marsh }\end{array}$ & $\begin{array}{l}\text { Mor- } \\
\text { ris } \\
\text { Island }\end{array}$ & $\begin{array}{l}\text { Sow } \\
\text { Pond }\end{array}$ & $\begin{array}{l}\text { Toms } \\
\text { Cove } \\
\text { (West) }\end{array}$ & $\begin{array}{l}\text { Wal- } \\
\text { lops } \\
\text { Island }\end{array}$ & $\begin{array}{l}\text { Assa- } \\
\text { wom- } \\
\text { an } \\
\text { Island }\end{array}$ & $\begin{array}{l}\text { Cedar } \\
\text { Island }\end{array}$ & & \\
\hline 1 & $\mathrm{~A}$ & A & B & $\mathrm{A}$ & $\mathrm{A}$ & $\mathrm{A}$ & $\mathrm{A}$ & $\mathrm{A}$ & $\mathrm{A}$ & A & $\mathrm{A}$ & A & 0 & 6.337 \\
\hline 2 & A & A & $\mathrm{B}$ & $\mathrm{C}$ & $\mathrm{C}$ & $\mathrm{A}$ & $\mathrm{A}$ & $\mathrm{A}$ & $\mathrm{C}$ & A & A & A & 14,880 & 6.503 \\
\hline 3 & $\mathrm{C}$ & A & $\mathrm{B}$ & $\mathrm{C}$ & $\mathrm{C}$ & A & A & A & $\mathrm{C}$ & A & A & A & 21,820 & 6.560 \\
\hline 4 & B & $\mathrm{C}$ & $\mathrm{B}$ & $\mathrm{C}$ & $\mathrm{C}$ & A & A & A & $\mathrm{C}$ & A & A & A & 48,046 & 6.618 \\
\hline 5 & B & B & B & B & $\mathrm{C}$ & A & A & A & $\mathrm{C}$ & A & A & A & 97,235 & 6.656 \\
\hline 6 & B & B & B & B & B & A & A & A & $\mathrm{C}$ & A & A & A & 119,368 & 6.666 \\
\hline 7 & B & B & B & B & $\mathrm{C}$ & A & A & B & $\mathrm{C}$ & A & A & A & $2,497,235$ & 6.972 \\
\hline 8 & B & B & B & B & B & A & A & B & B & A & A & A & $2,728,368$ & 6.982 \\
\hline 9 & B & B & B & B & B & A & A & B & $\mathrm{C}$ & B & A & A & $6,944,368$ & 7.201 \\
\hline 10 & B & D & B & B & B & A & A & B & B & B & A & A & $13,069,168$ & 7.402 \\
\hline 11 & B & B & B & B & B & B & A & B & $\mathrm{C}$ & B & A & A & $17,169,368$ & 7.567 \\
\hline 12 & B & D & B & B & B & B & A & B & $\mathrm{C}$ & B & A & A & $23,085,168$ & 7.767 \\
\hline 13 & B & D & $\mathrm{C}$ & B & B & A & B & B & $\mathrm{C}$ & B & A & A & $29,885,168$ & 7.949 \\
\hline 14 & B & B & $\mathrm{C}$ & B & B & B & B & B & $\mathrm{C}$ & B & A & A & $34,194,368$ & 8.115 \\
\hline 15 & B & D & $\mathrm{C}$ & B & B & B & B & B & $\mathrm{C}$ & B & A & A & $40,110,168$ & 8.315 \\
\hline 16 & B & B & $\mathrm{C}$ & B & B & B & B & B & $\mathrm{C}$ & B & A & B & $55,844,368$ & 8.497 \\
\hline 17 & B & D & $\mathrm{C}$ & B & B & B & B & B & $\mathrm{C}$ & B & A & B & $61,760,168$ & 8.698 \\
\hline 18 & B & B & $\mathrm{C}$ & B & B & B & B & B & $\mathrm{C}$ & B & B & B & $76,844,368$ & 8.836 \\
\hline 19 & B & D & $\mathrm{C}$ & B & B & $\mathrm{B}$ & B & $\mathrm{B}$ & $\mathrm{C}$ & B & B & B & $82,760,168$ & 9.037 \\
\hline
\end{tabular}

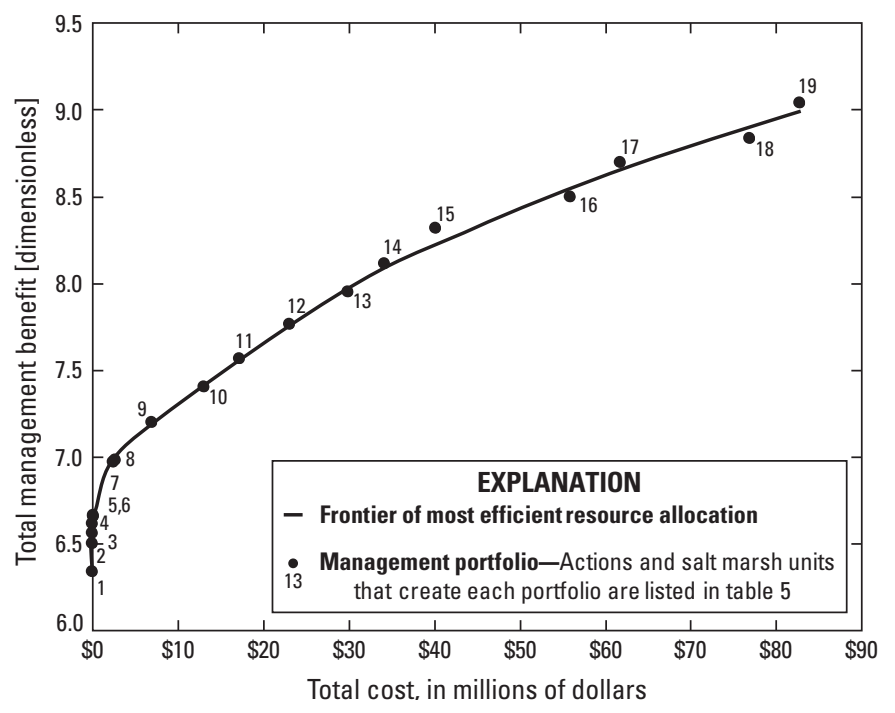

Figure 3. Predicted total management benefit of various portfolios, expressed as weighted utilities, relative to total annual cost at the Chincoteague National Wildlife Refuge in Virginia. Each portfolio (dot with number) represents a combination of twelve management actions, one per salt marsh unit, as identified in table 5 . The line represents the efficient frontier for resource allocation. 


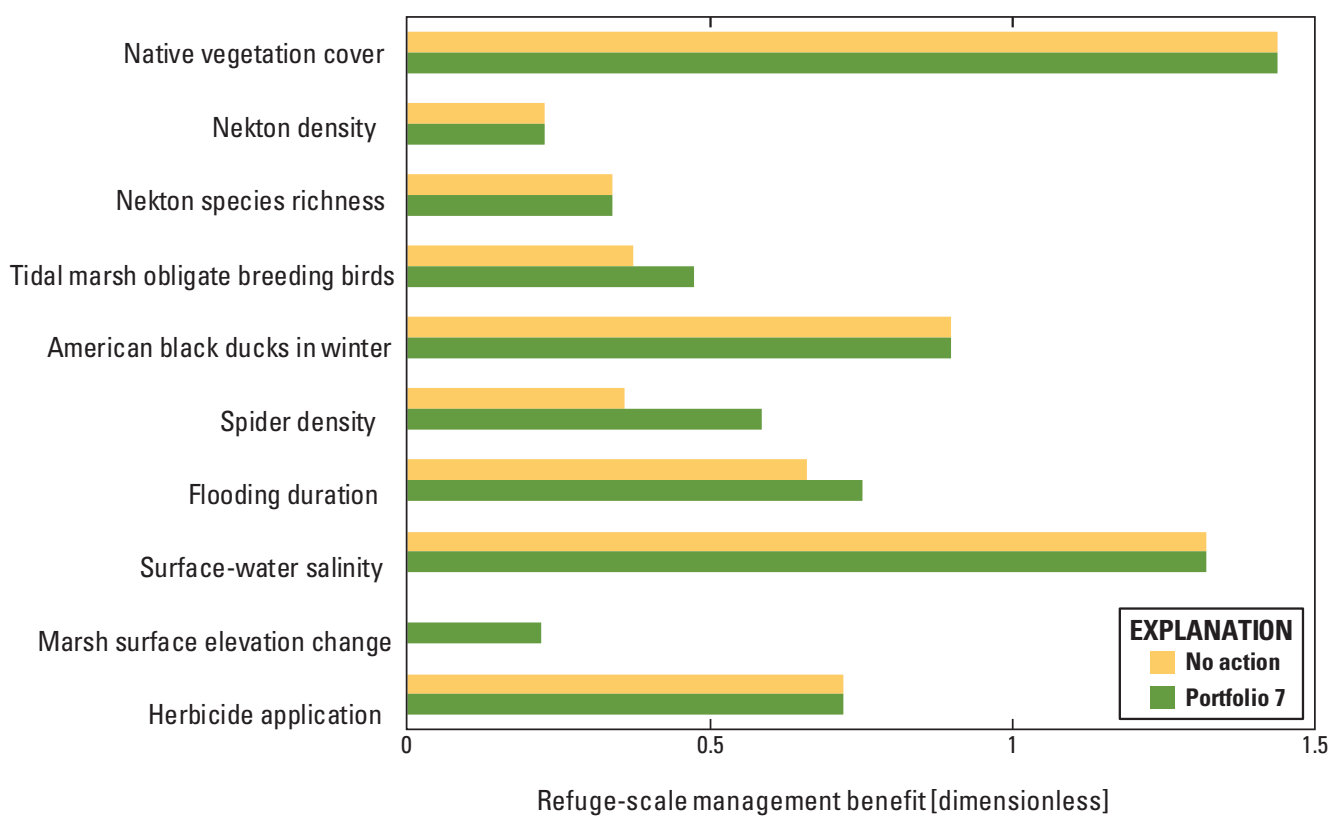

Figure 4. Predicted management benefit at the refuge scale for individual performance metrics, expressed as weighted utilities, resulting from implementation of the management actions included in portfolio 7, in comparison to the management benefit from the baseline "no-action" portfolio at the Chincoteague National Wildlife Refuge in Virginia. The baseline ("no-action") predicted management benefit for marsh surface elevation change is zero. The actions included in each portfolio are listed in table 5.

\section{Considerations for Optimizing Salt Marsh Management}

A regional structured decision-making framework for salt marshes on NWRs in the northeastern United States was applied by the USGS, in cooperation with the FWS, to develop a tool for optimizing management decisions at the Chincoteague National Wildlife Refuge. Use of the existing regional framework and a rapid-prototyping approach permitted NWR biologists and managers, FWS regional authorities, and research scientists to construct a decision model for the refuge within the confines of a 1.5-day workshop. This preliminary prototype provides a local framework for decision making while revealing information needs for future iterations. Insights from this process may also be useful to inform future habitat management planning at the refuge.

The suite of potential management actions and predicted outcomes included in this prototype (table 3 ) were based on current understanding of the Chincoteague National Wildlife Refuge salt marshes and hypothesized process-response pathways (app. 1). Tidal flooding is the predominant physical control on the structure and function of salt marsh ecosystems (Pennings and Bertness, 2001), and there is widespread scientific effort to elucidate how salt marshes may respond to accelerating rates of sea-level rise (Kirwan and Megonigal,
2013; Roman, 2017). The Chincoteague National Wildlife Refuge is committed to working with partners on research and assessment of future sea-level rise scenarios and potential effects on Delmarva Peninsula habitats (FWS, 2015). New information on how climate change is expected to influence salt marshes at the refuge (FWS, 2015) may alter or augment the management actions considered to enhance marsh sustainability as well as the predicted responses to management interventions. In addition, during construction of the regional decision model, lack of widely available data on rates of vertical marsh growth led to the adoption of a very coarse scale of measurement for change in marsh surface elevation relative to sea-level rise (table 1). In 2013, surface elevation tables (Lynch and others, 2015) were installed in each salt marsh unit to obtain accurate measurements of marsh surface elevation change (S.C. Adamowicz and T. Mikula, FWS, unpub. data, 2017). The availability of this information would be expected to improve management predictions during subsequent iterations of this structured decision-making framework.

Results of constrained optimizations (table 5) based on the objectives, management actions, and predicted outcomes included in this prototype identified three major areas for improvement. First, thin-layer deposition of dredged sediments on the marsh surface was the only potential management action identified for six of the refuge's salt marsh units (table 3 ). Sediment additions are increasingly proposed to 
enhance sustainability of northeastern salt marshes (Wigand and others, 2017), although it is recognized that factors influencing the long-term success are not fully understood (Roman, 2017). Application of thin-layer deposition at the Chincoteague National Wildlife Refuge was predicted to increase management benefit substantially (table 4), but the estimated high cost of implementation excluded this action from portfolios with total cost constraints less than $\$ 2.497$ million. This may lead managers to seek lower cost alternatives for prolonging marsh integrity at the Chincoteague National Wildlife Refuge; increased scientific understanding of conditions under which thin-layer deposition enhances marsh resilience could be expected to assist in determining the efficacy of sediment deposition as a management tool. Second, although marsh loss through shoreface erosion was identified as a management concern within two salt marsh units (South Wash Flats and Toms Cove [West]), installing oyster castles to attenuate wave action was never selected for implementation in South Wash Flats and had a very small effect on the predicted total management benefit compared with the "no-action" alternative in Toms Cove (West). Deconstructing the objective of maintaining the extent of the marsh platform into subordinate objectives and performance metrics related to both horizontal and vertical gains and losses may provide more refined information for decision making. Finally, the constrained optimizations analyzed in this report were based on approximations of management costs. As salt marsh management is implemented around the region, a list of actual expenses can be compiled, so that future iterations of the decision model can include more accurate cost estimates.

The prototype model for the Chincoteague National Wildlife Refuge provides a useful tool for decision making that can be updated in the future with new data and information. The spatial and temporal variability inherent in parameter estimates were not quantified during rapid prototyping. Previously, preliminary sensitivity analysis revealed little effect of incorporating ecological variation in abundance of marshobligate breeding birds on the optimal solutions for Prime Hook National Wildlife Refuge (Neckles and others, 2015). This lends confidence to use of this framework for decision making; however, including probability distributions for each performance metric in the decision model could be a high priority for future prototypes. Future monitoring of salt marsh integrity performance metrics will be useful to refine baseline parameter estimates, and feedback from measured responses to management actions around the region will help reduce uncertainties surrounding management predictions. The structured decision-making framework applied here to the Chincoteague National Wildlife Refuge is based on a hierarchy of regional objectives and regional value functions relating performance metrics to perceived management benefits. It will be important to ensure that subsequent iterations reflect evolving management objectives and desired outcomes. Elements of the decision model could be further adapted, for example through differential weighting of objectives or altered value functions, to reflect specific, local management goals and mandates.
Future optimization analyses that use this framework could also incorporate additional constraints on action selection, such as ensuring that particular actions within individual salt marsh units are included in optimal management portfolios, to further tailor the model to refuge-specific needs.

\section{References Cited}

Association of Fish and Wildlife Agencies, 2019, North American bird conservation initiative: Association of Fish and Wildlife Agencies web page, accessed April 23, 2019, at https://www.fishwildlife.org/afwa-inspires/ north-american-bird-conservation-initiative.

Blomquist, S.M., Johnson, T.D., Smith, D.R., Call, G.P., Miller, B.N., Thurman, W.M., McFadden, J.E., Parkin, M.J., and Boomer, G.S., 2010, Structured decision-making and rapid prototyping to plan a management response to an invasive species: Journal of Fish and Wildlife Management, v. 1, no. 1, p. 19-32. [Also available at https://doi.org/10.3996/JFWM-025.]

Conroy, M.J., and Peterson, J.T., 2013, Decision making in natural resource management-A structured, adaptive approach: West Sussex, John Wiley and Sons, Ltd., 456 p.

Cowardin, L.M., Carter, V., Golet, F.C., and LaRoe, E.T., 1979, Classification of wetlands and deepwater habitats of the United States: U.S. Fish and Wildlife Service FWS/OBS-79/31, 131 p., accessed November 12, 2018, at https://www.fws.gov/wetlands/Documents/ Classification-of-Wetlands-and-Deepwater-Habitats-of-theUnited-States.pdf.

Garrard, G.E., Rumpff, L., Runge, M.C., and Converse, S.J., 2017, Rapid prototyping for decision structuring-An efficient approach to conservation decision analysis, in Bunnefeld, N., Nicholson, E., and Milner-Gulland, E.J., eds., Decision-making in conservation and natural resource management: Cambridge, United Kingdom, Cambridge University Press, p. 46-64.

Gedan, K.B., Altieri, A.H., and Bertness, M.D., 2011, Uncertain future of New England salt marshes: Marine Ecology Progress Series, v. 434, p. 229-237. [Also available at https://doi.org/10.3354/meps09084.]

Gedan, K.B., Silliman, B.R., and Bertness, M.D., 2009, Centuries of human-driven change in salt marsh ecosystems: Annual Review of Marine Science, v. 1, no. 1, p. 117-141. [Also available at https://doi.org/10.1146/ annurev.marine.010908.163930.] 
Gregory, R., Failing, L., Harstone, M., Long, G., McDaniels, T., and Ohlson, D., 2012, Structured decision making-A practical guide to environmental management choices: West Sussex, John Wiley and Sons, Ltd., 299 p.

Gregory, R.S., and Keeney, R.L., 2002, Making smarter environmental management decisions: Journal of the American Water Resources Association, v. 38, no. 6, p. 1601-1612. [Also available at https://doi.org/10.1111/j.1752-1688.2002.tb04367.x.]

Hammond, J.S., Keeney, R.L., and Raiffa, H., 1999, Smart choices-A practical guide to making better life decisions: Boston, Harvard Business School Press, 242 p.

Keeney, R.L., and Raiffa, H., 1993, Decisions with multiple objectives-Preferences and value tradeoffs: Cambridge University Press, 569 p.

Kirkwood, C.W., 1997, Strategic decision making-Multiobjective decision analysis with spreadsheets: Belmont, Duxbury Press, 345 p.

Kirwan, M.L., and Megonigal, J.P., 2013, Tidal wetland stability in the face of human impacts and sea-level rise: Nature, v. 504, no. 7478, p. 53-60. [Also available at https://doi.org/10.1038/nature12856.]

Lynch, J.C., Hensel, P., and Cahoon, D.R., 2015, The surface elevation table and marker horizon technique-A protocol for monitoring wetland elevation dynamics: National Park Service Natural Resource Report NPS/NCBN/NRR 2015/1078, [variously paged], accessed August 24, 2018, at https://irma.nps.gov/DataStore/DownloadFile/531681.

Neckles, H.A., Guntenspergen, G.R., Shriver, W.G., Danz, N.P., Wiest, W.A., Nagel, J.L., and Olker, J.H., 2013, Identification of metrics to monitor salt marsh integrity on national wildlife refuges in relation to conservation and management objectives-Final report to U.S. Fish and Wildlife Service, Northeast Region: U.S. Geological Survey Patuxent Wildlife Research Center, 226 p., accessed May 1, 2018, at https://ecos.fws.gov/ServCat/Reference/ Profile/37795.
Neckles, H.A., Lyons, J.E., Guntenspergen, G.R., Shriver, W.G., and Adamowicz, S.C., 2015, Use of structured decision making to identify monitoring variables and management priorities for salt marsh ecosystems: Estuaries and Coasts, v. 38, no. 4, p. 1215-1232. [Also available at https://doi.org/10.1007/s12237-014-9822-5.]

Pennings, S.C., and Bertness, M.D., 2001, Salt marsh communities, in Bertness, M.D., Gaines, S.D., and Hay, M.E., eds., Marine community ecology: Sunderland, Mass., Sinauer Associates, p. 289-316.

Roman, C.T., 2017, Salt marsh sustainability-Challenges during an uncertain future: Estuaries and Coasts, v. 40, no. 3, p. 711-716. [Also available at https://doi.org/10.1007/ s12237-016-0149-2.]

Steinkamp, M., 2008. New England/mid-Atlantic coast bird conservation (BCR 30) implementation plan: Laurel, Md., Atlantic Coast Joint Venture, 251 p., accessed August 15, 2018, at http://www.acjv.org/ BCR_30/BCR30_June_23_2008_final.pdf.

U.S. Fish and Wildlife Service (FWS), 2015, Chincoteague and Wallops Island National Wildlife Refuges - Comprehensive conservation plan: U.S. Fish and Wildlife Service, [variously paged], accessed August 15, 2018, at https://www.fws.gov/uploadedFiles/CCP_Volume1.pdf.

U.S. Geological Survey, 2014, National land cover database (NLCD) -2011: U.S. Geological Survey data release, accessed April 4, 2019, at https:/www.sciencebase.gov/ catalog/item/513624bae4b03b8ec4025c4d.

Wigand, C., Ardito, T., Chaffee, C., Ferguson, W., Paton, S., Raposa, K., Vandemoer, C., and Watson, E., 2017, A climate change adaptation strategy for management of coastal marsh systems: Estuaries and Coasts, v. 40, no. 3, p. 682-693. [Also available at https://doi.org/10.1007/ s12237-015-0003-y.] 

Appendixes 1-2 


\section{Appendix 1. Regional Influence Diagrams}

The influence diagrams (following the style of prototype diagrams in Neckles and others, 2015) in this appendix (figs. 1.1-1.8) relate possible management strategies to performance metrics. Shapes represent elements of decisions, as follows: rectangles for actions, rectangles with rounded corners for deterministic factors, ovals for stochastic events, and hexagons for consequences expressed as a performance metric.

\section{Reference Cited}

Neckles, H.A., Lyons, J.E., Guntenspergen, G.R., Shriver, W.G., and Adamowicz, S.C., 2015, Use of structured decision making to identify monitoring variables and management priorities for salt marsh ecosystems: Estuaries and Coasts, v. 38, no. 4, p. 1215-1232. [Also available at https://doi.org/10.1007/s12237-014-9822-5.]

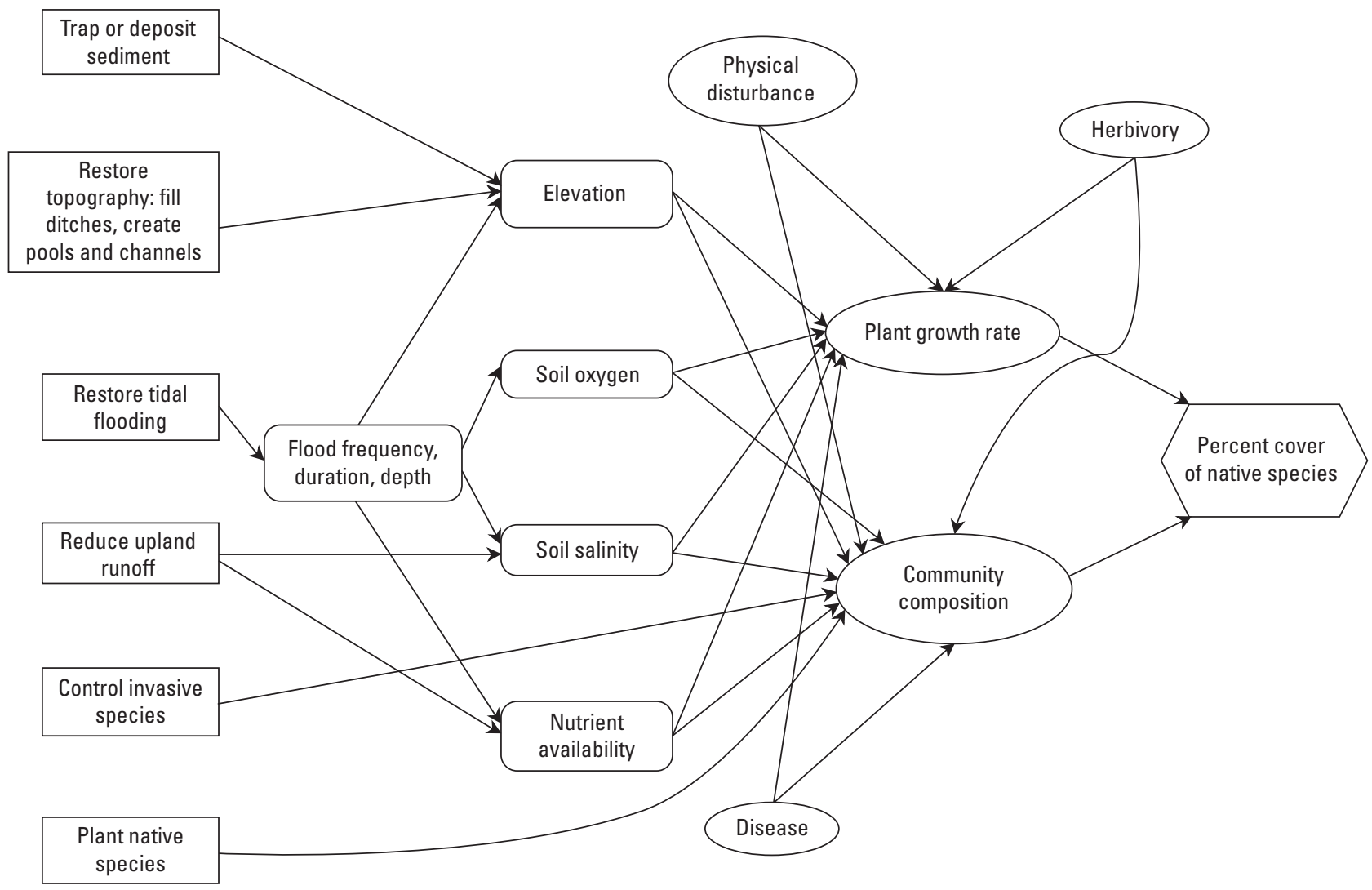

Figure 1.1. Influence diagram used to estimate percent cover of native vegetation in response to implementing certain management actions. 


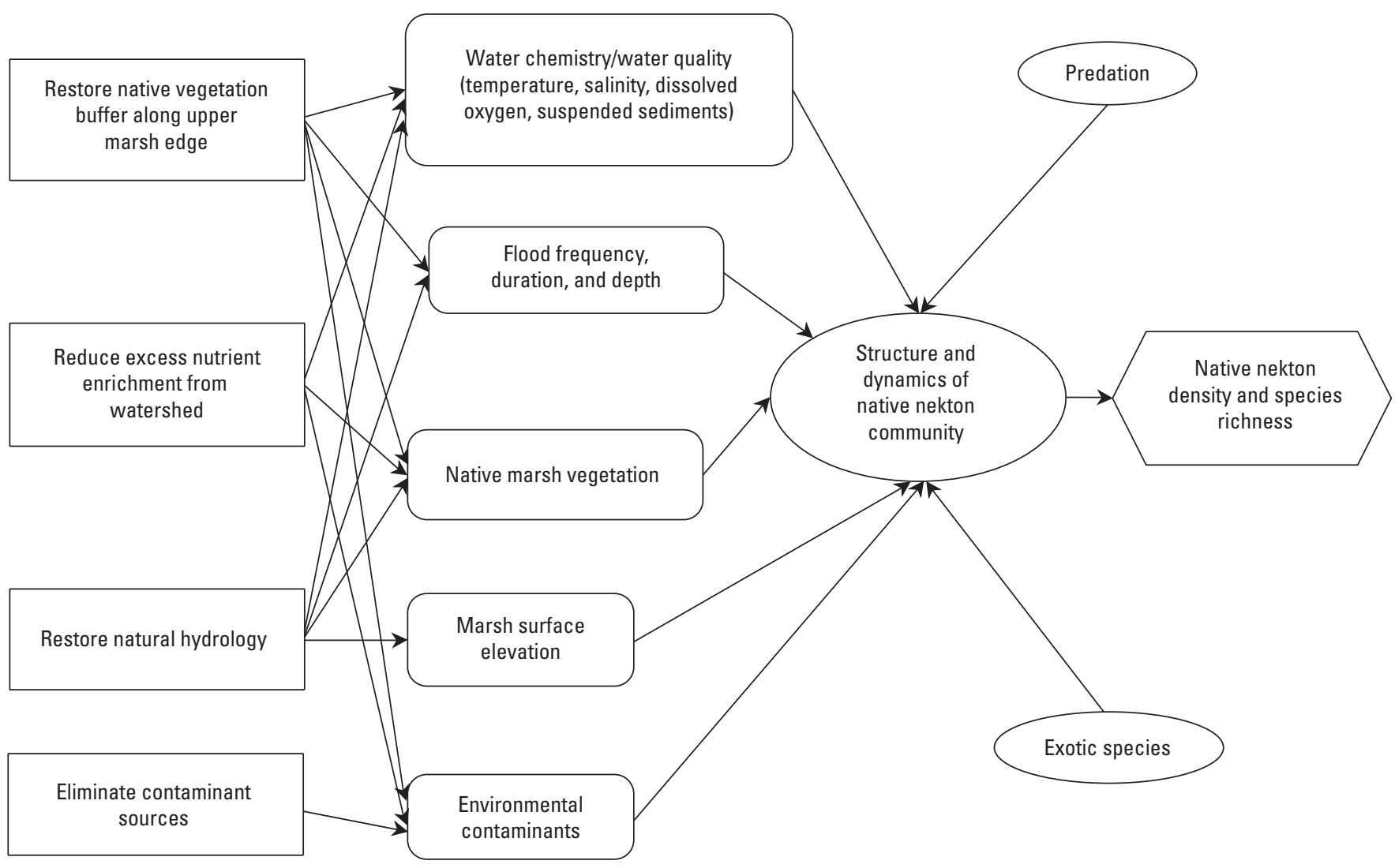

Figure 1.2. Influence diagram used to estimate nekton density and species richness in response to implementing certain management actions. 


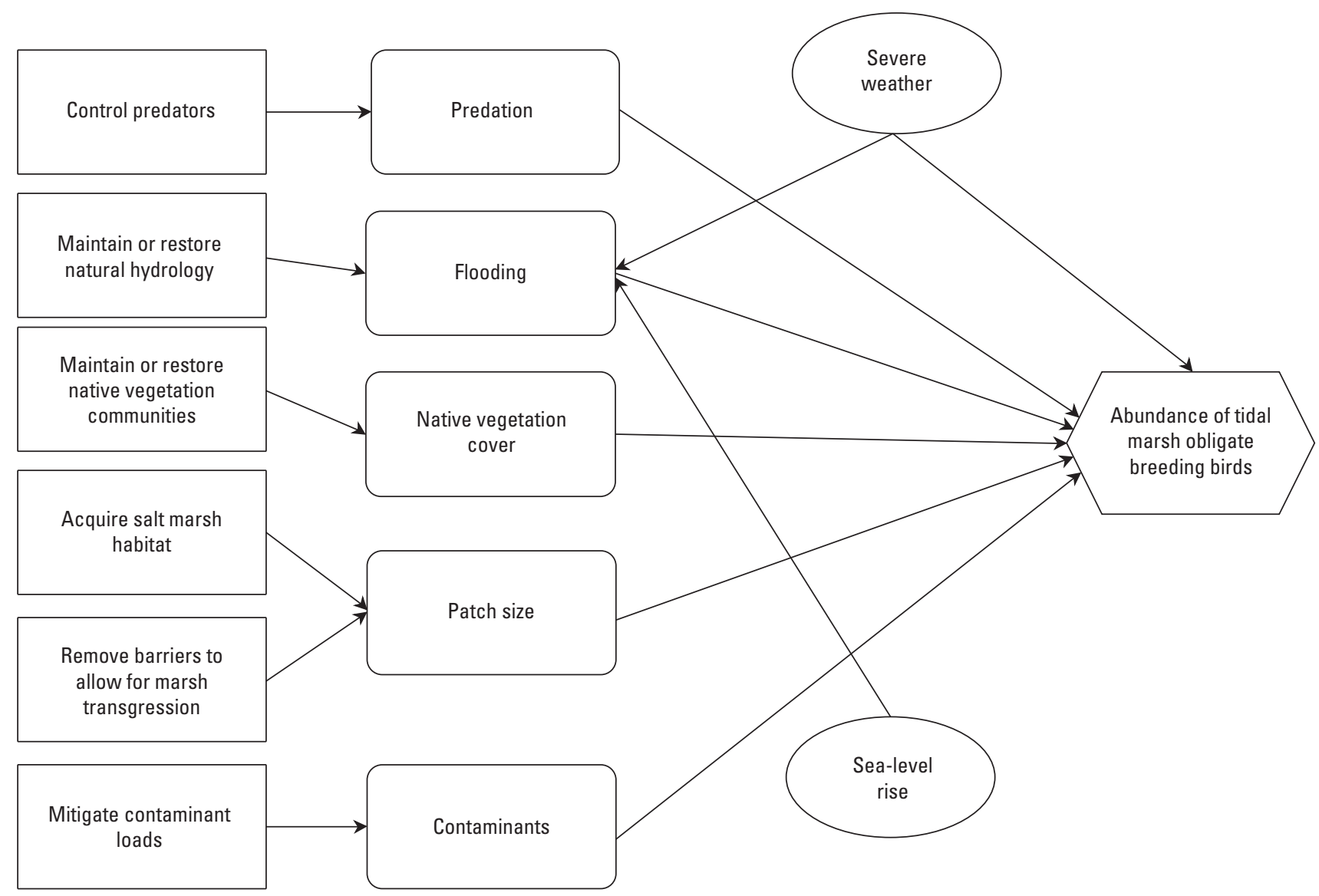

Figure 1.3. Influence diagram used to estimate abundance of tidal marsh obligate breeding birds in response to implementing certain management actions. 


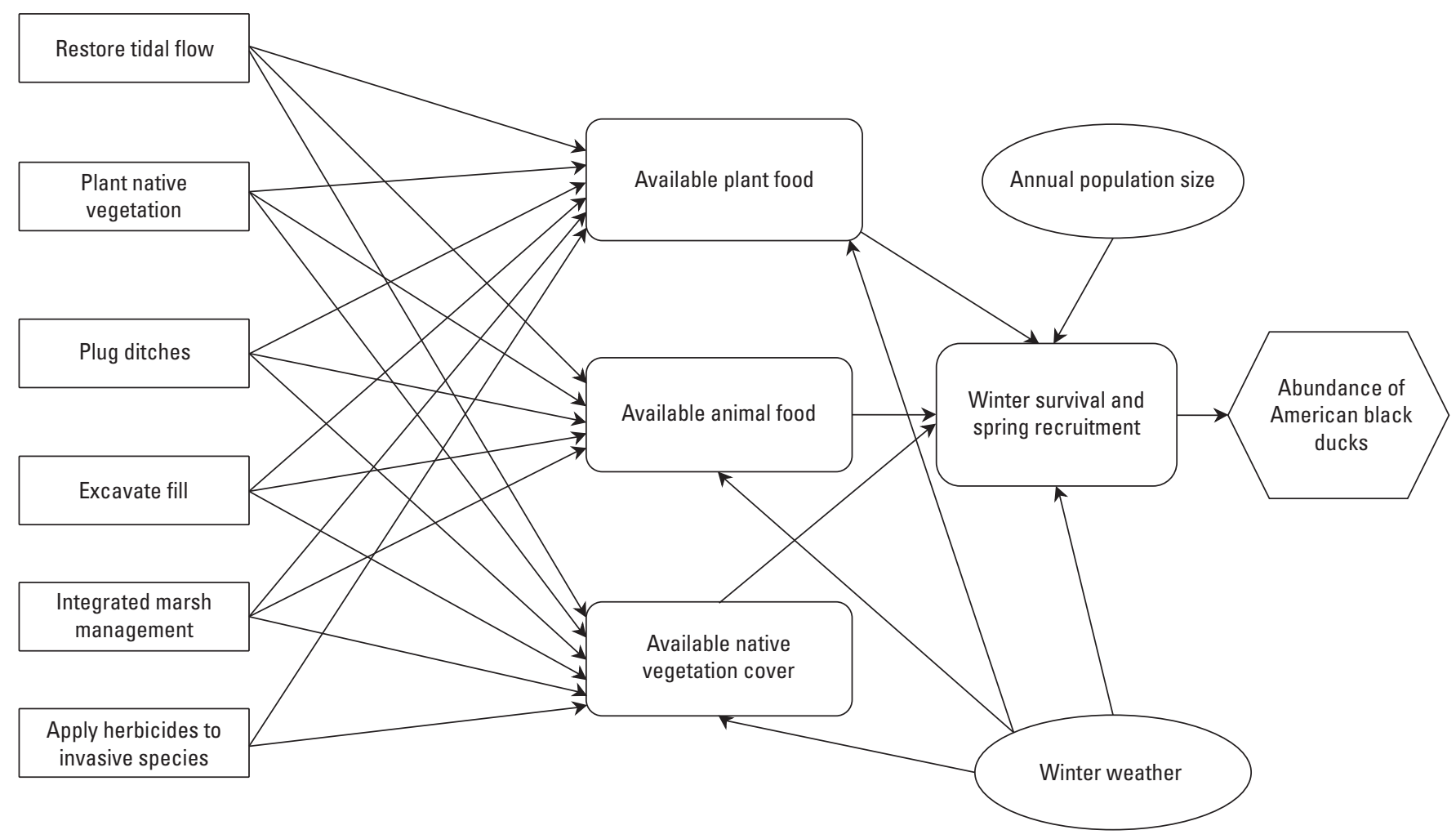

Figure 1.4. Influence diagram used to estimate abundance of American black ducks in winter, as indicator species for nonbreeding wetland birds, in response to implementing certain management actions. 


\section{Optimization of Salt Marsh Management at the Chincoteague National Wildlife Refuge, Virginia}

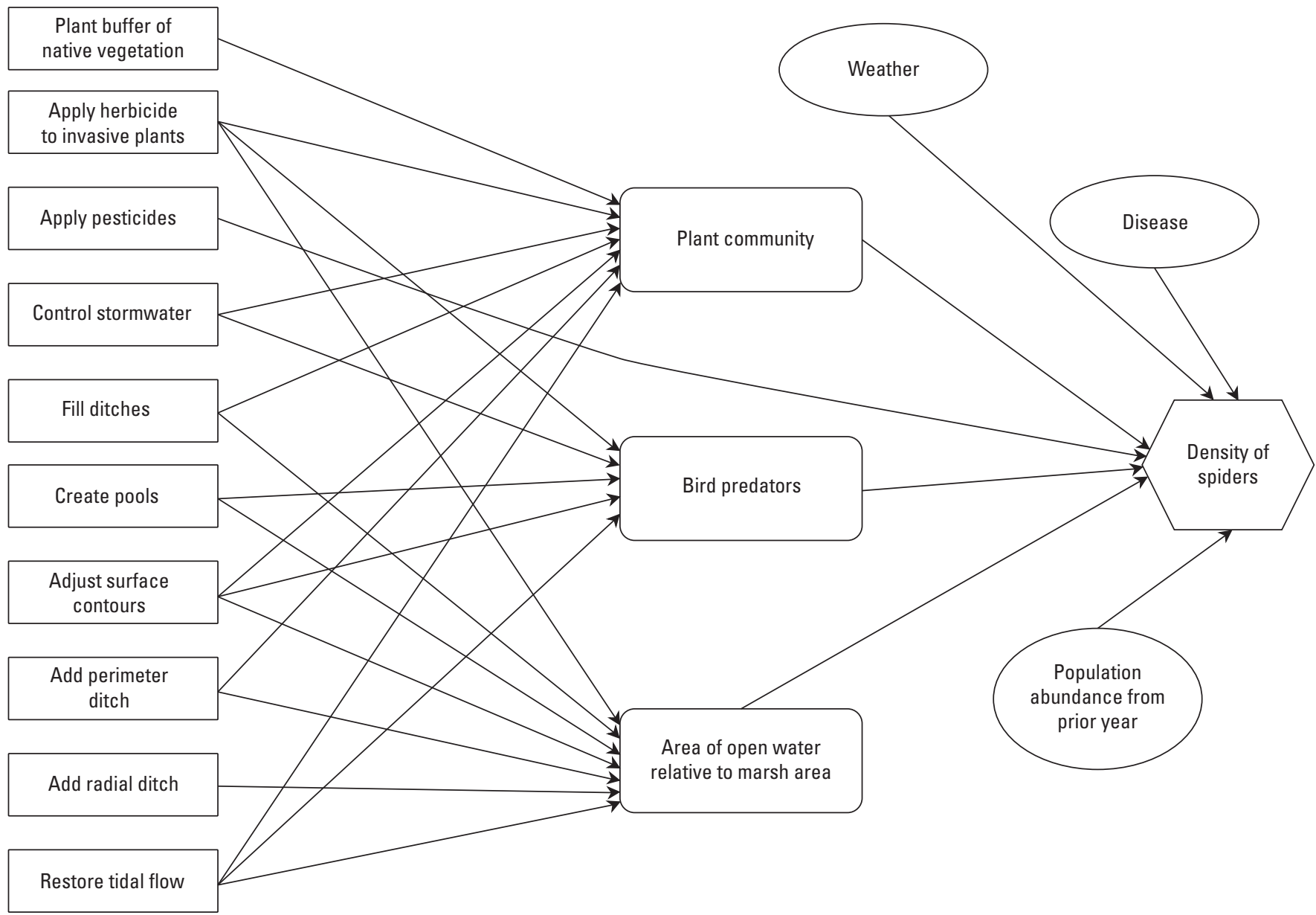

Figure 1.5. Influence diagram used to estimate density of spiders, as indicator of trophic health, in response to implementing certain management actions. 


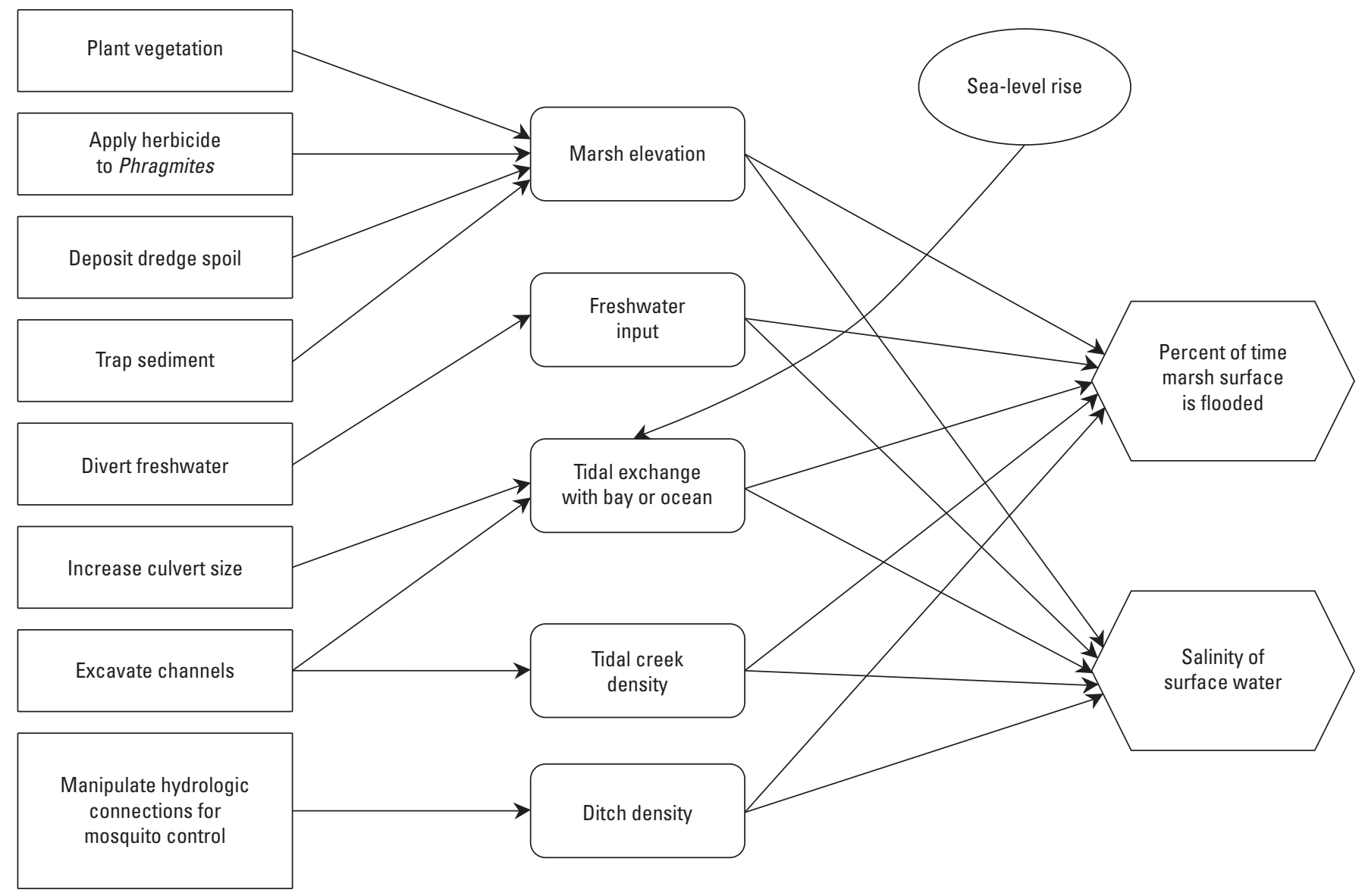

Figure 1.6. Influence diagram used to estimate percent of time marsh surface is flooded and salinity of marsh surface water in response to implementing certain management actions. 


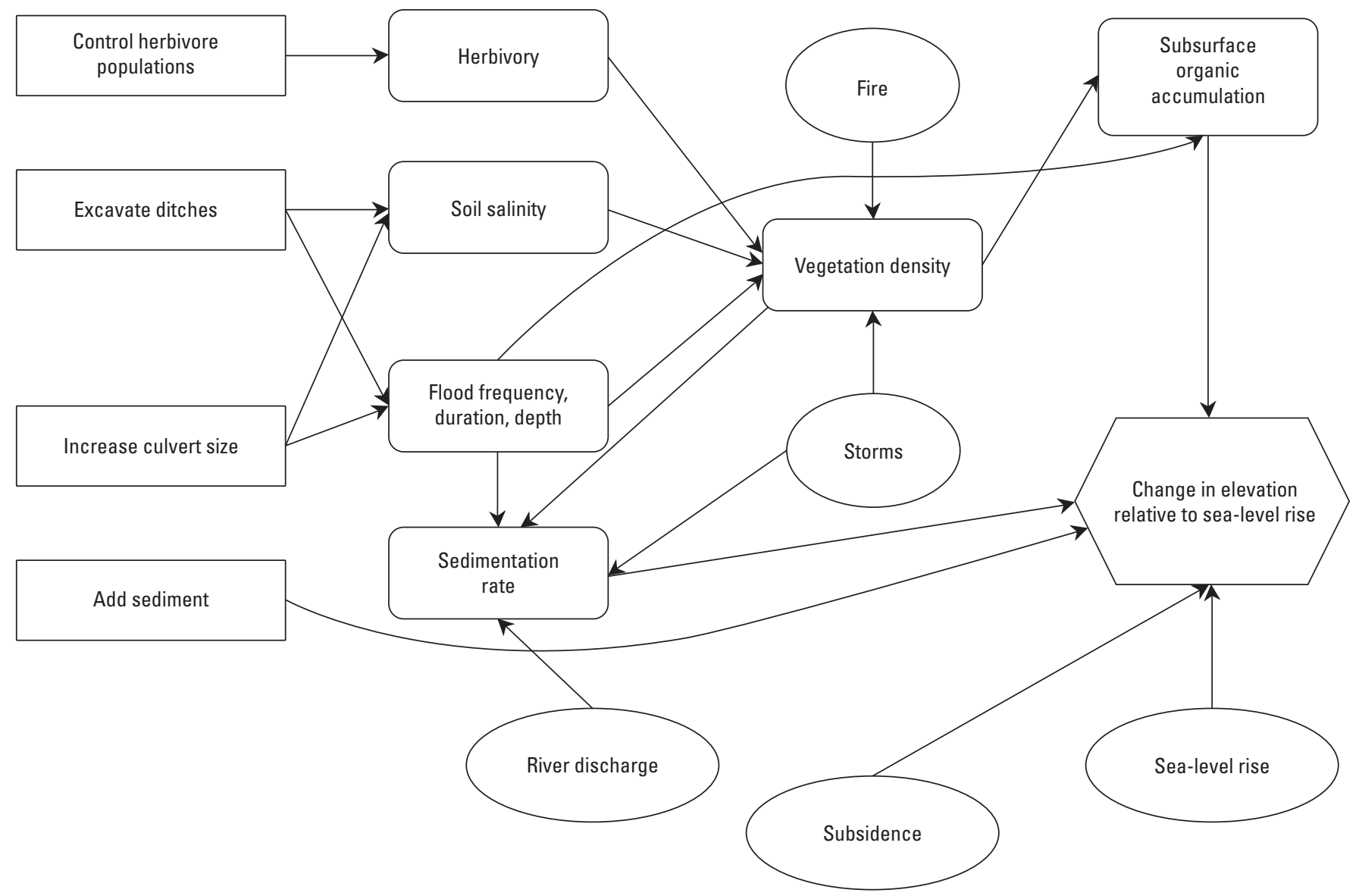

Figure 1.7. Influence diagram used to estimate change in elevation of the marsh surface relative to sea-level rise in response to implementing certain management actions.

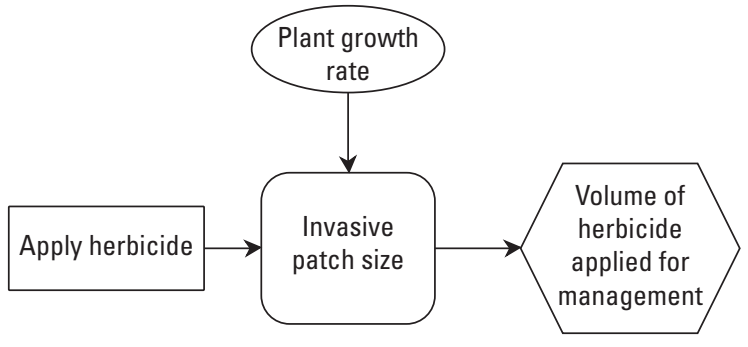

Figure 1.8. Influence diagram used to estimate volume of herbicide that would be applied if decision was made to use chemical control for removing unwanted vegetation. 


\section{Appendix 2. Utility Functions for the Chincoteague National Wildlife Refuge}

Utilities $[u(x)]$ are derived as monotonically increasing, monotonically decreasing, or step functions over the range of performance metric $x$. In the functions in figures 2.1 through 2.10, $x$, Low, High, and $\rho$ are expressed in performance metric units; Low and High represent the endpoints of the given metric range for the Chincoteague National Wildlife Refuge; and $\rho$ represents a shape parameter derived by stakeholder elicitation (Neckles and others, 2015). Break points in step functions were also derived by stakeholder elicitation.

\section{Reference Cited}

Neckles, H.A., Lyons, J.E., Guntenspergen, G.R., Shriver, W.G., and Adamowicz, S.C., 2015, Use of structured decision making to identify monitoring variables and management priorities for salt marsh ecosystems: Estuaries and Coasts, v. 38, no. 4, p. 1215-1232. [Also available at https://doi.org/10.1007/s12237-014-9822-5.]

$$
\begin{aligned}
u(x) & =\frac{1-e^{\frac{-(x-\text { Low })}{\rho}}}{1-e^{\frac{-(\text { High-Low })}{\rho}}} \\
\text { where } & \\
\text { Low } & =0 \\
\text { High } & =100 \\
\rho & =50
\end{aligned}
$$

Figure 2.1. Native vegetation at the Chincoteague National Wildlife Refuge, Virginia.

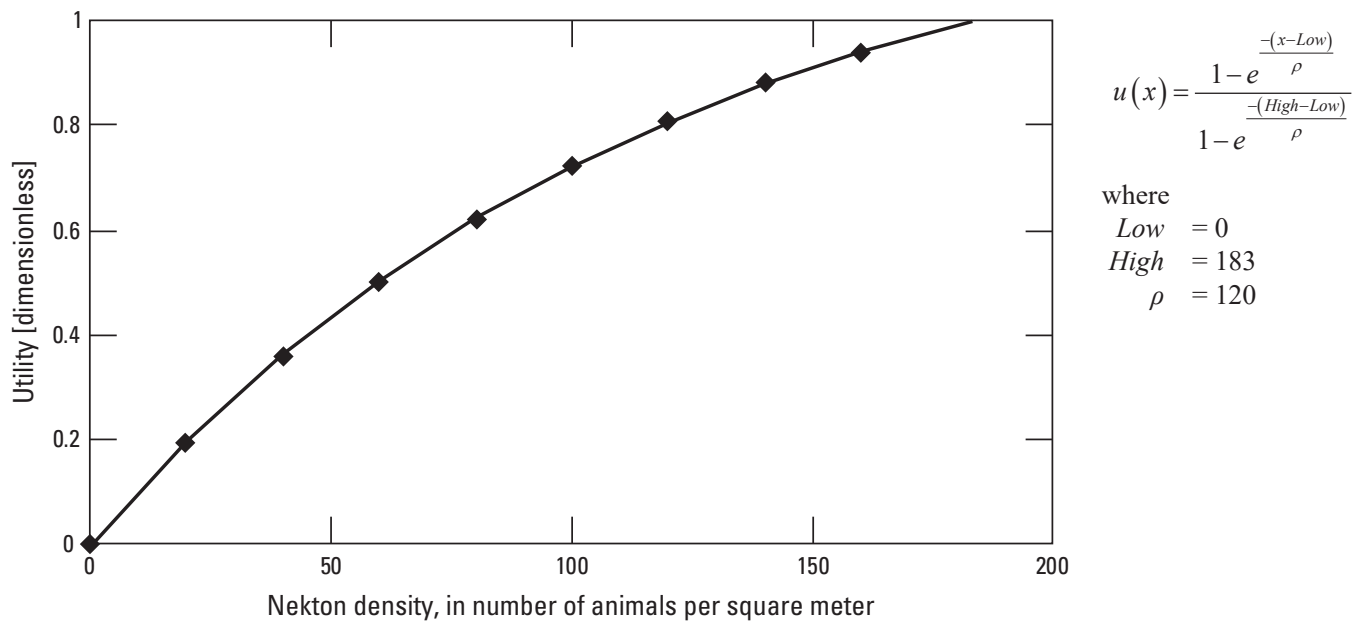

Figure 2.2. Native nekton density at the Chincoteague National Wildlife Refuge, Virginia. 


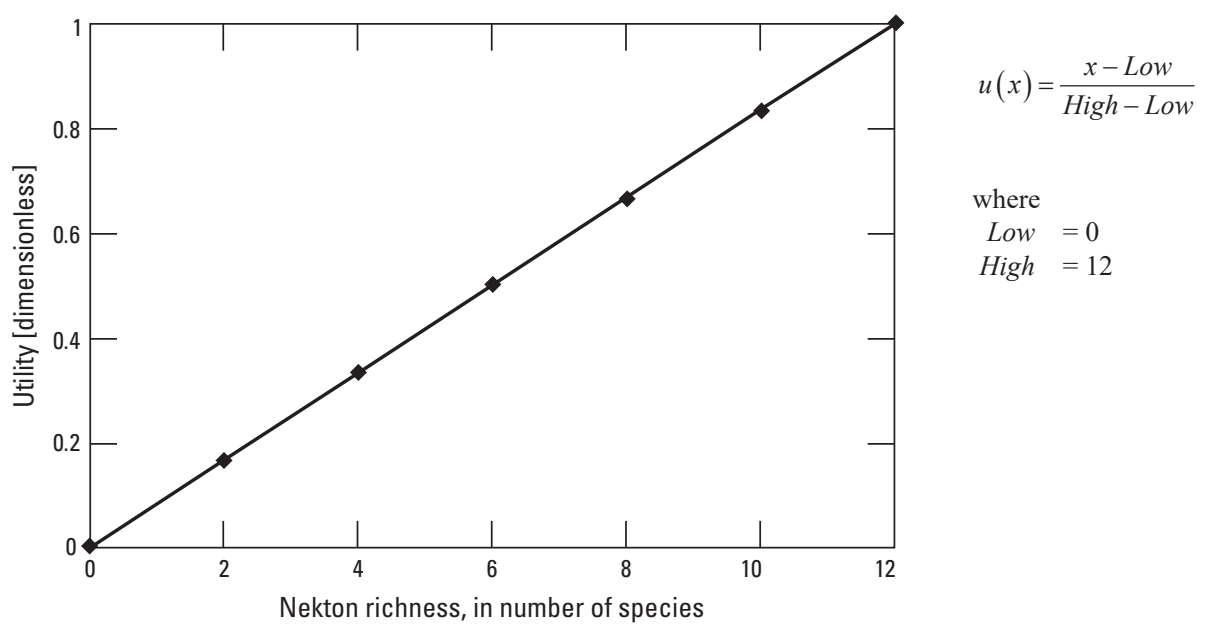

Figure 2.3. Native nekton species richness at the Chincoteague National Wildlife Refuge, Virginia.

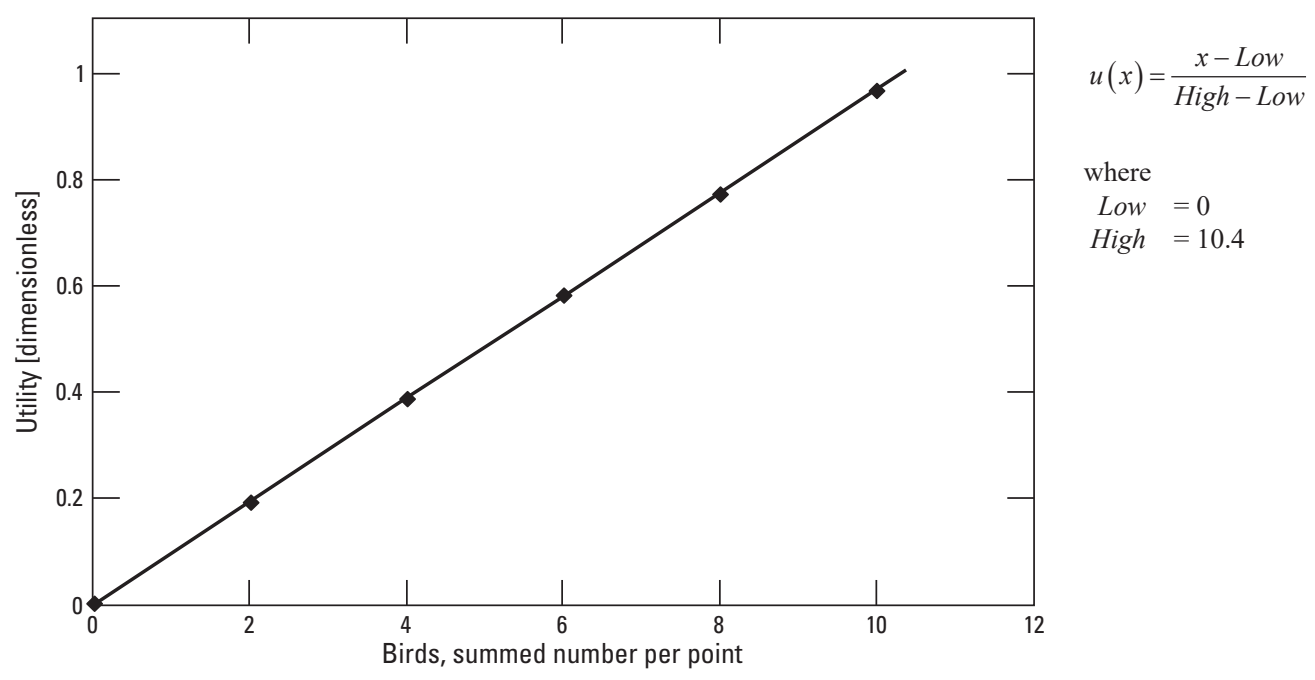

Figure 2.4. Tidal marsh obligate birds at the Chincoteague National Wildlife Refuge, Virginia. 


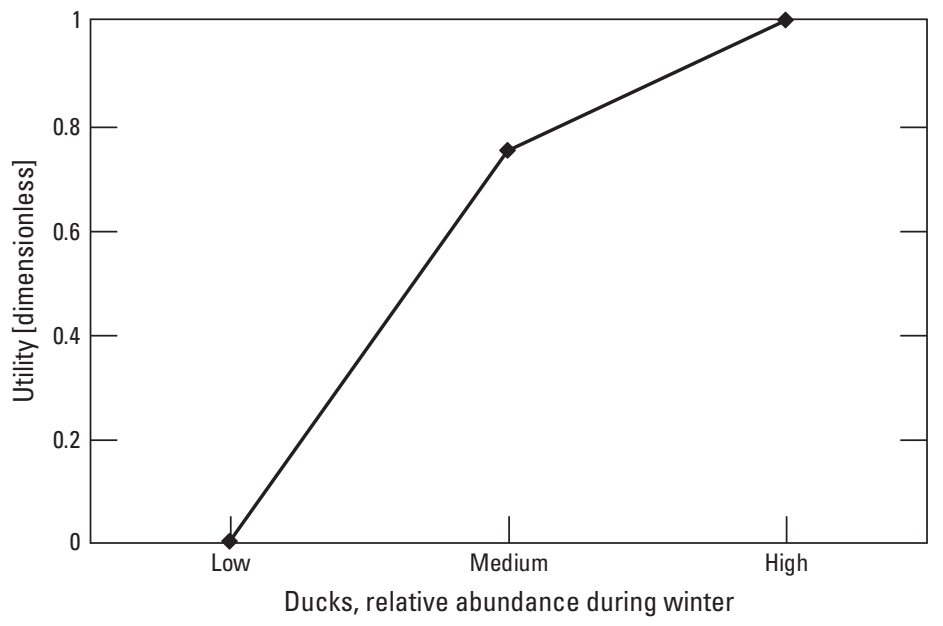

If $x=$ Low, then $u(x)=0$

If $x=$ Medium, then $u(x)=0.75$

If $x=H i g h$, then $u(x)=1$

Figure 2.5. American black ducks at the Chincoteague National Wildlife Refuge, Virginia.

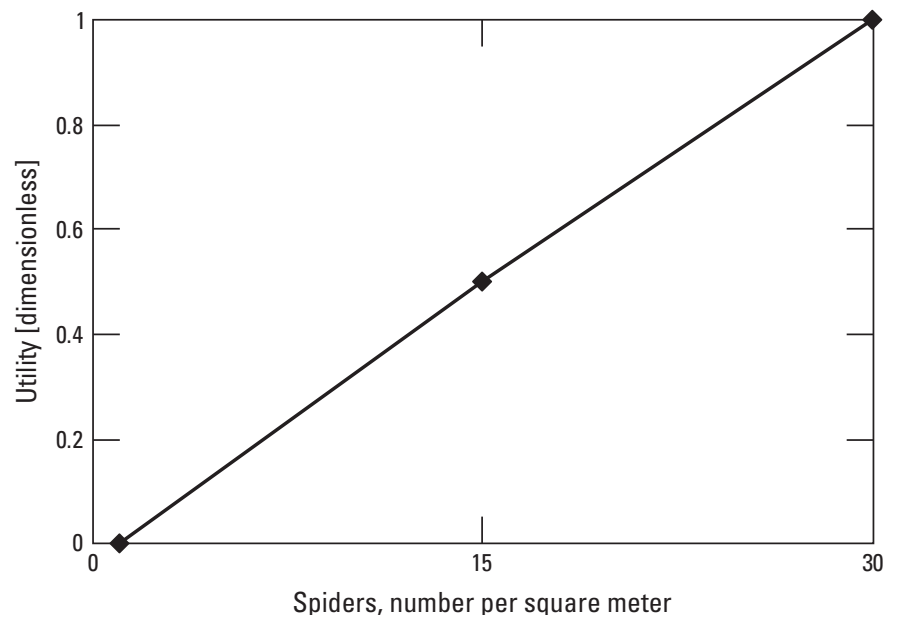

$$
\begin{aligned}
& \text { If } x \leq 15 \text {, then } u(x)=0.5 \times \frac{x-1}{14} \\
& \text { If } x>15 \text {, then } u(x)=0.5+\left(0.5 \times \frac{x-15}{15}\right)
\end{aligned}
$$

Figure 2.6. Marsh spiders at the Chincoteague National Wildlife Refuge, Virginia. 


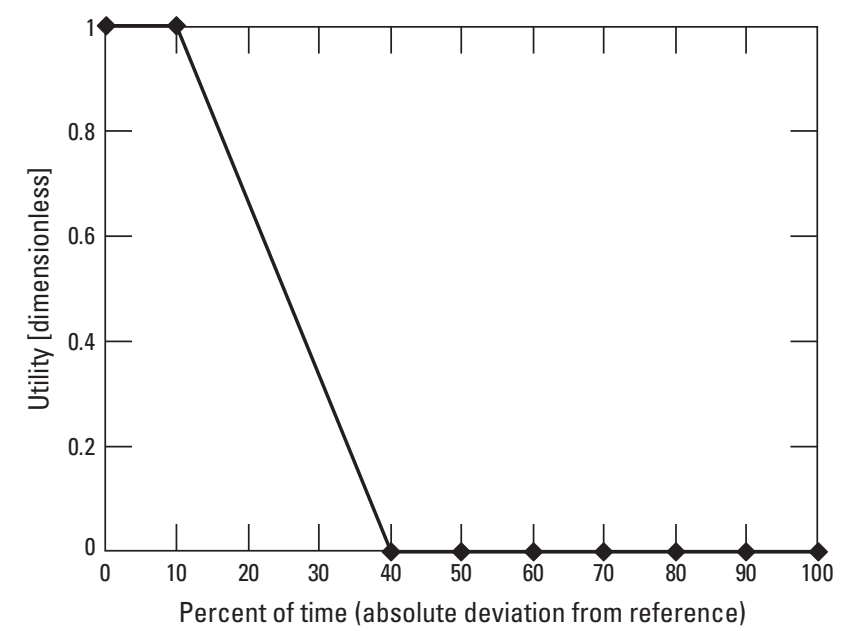

If $x \leq 10$, then $u(x)=1$

If $x \geq 40$, then $u(x)=0$
If $10<x<40$, then $u(x)=1-\frac{x-10}{30}$

Figure 2.7. Duration of surface flooding at the Chincoteague National Wildlife Refuge, Virginia.

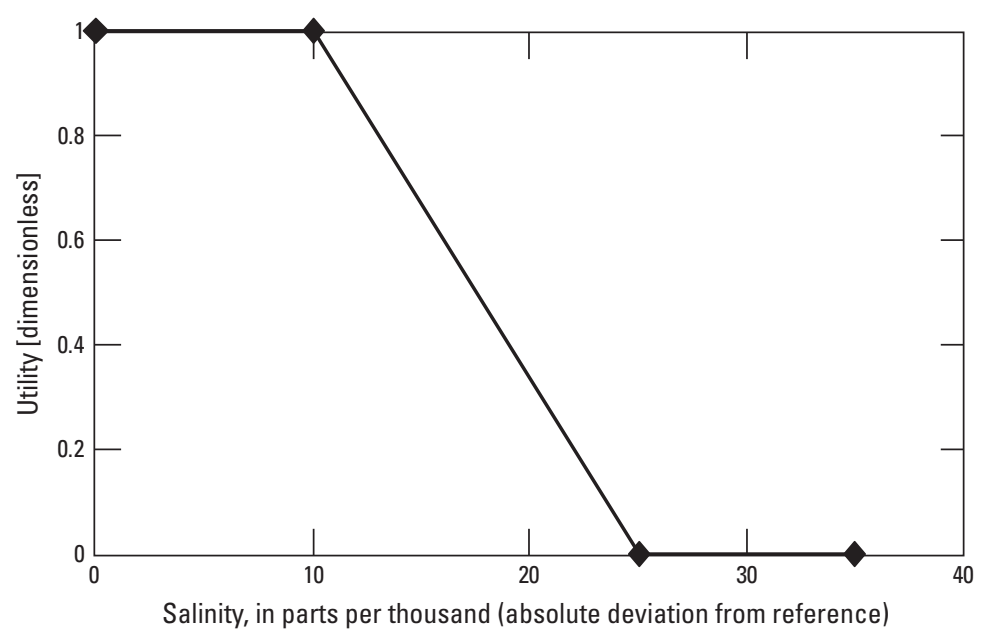

If $x \leq 10$, then $u(x)=1$

If $x \geq 25$, then $u(x)=0$

If $10<x<25$, then $u(x)=1-\frac{x-10}{15}$

Figure 2.8. Salinity of surface water at the Chincoteague National Wildlife Refuge, Virginia. 


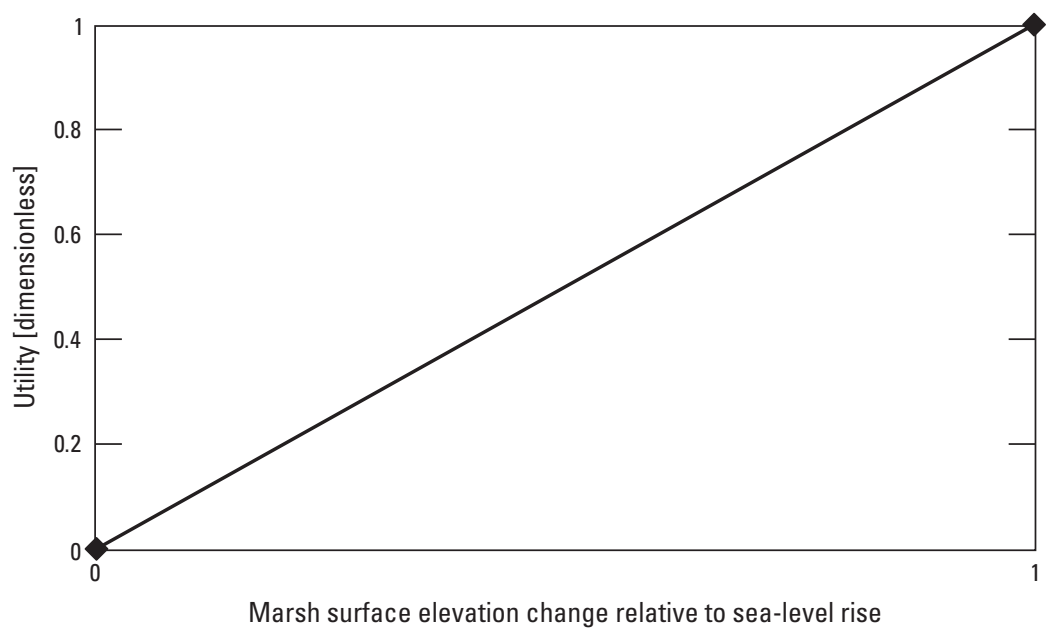

$$
\begin{aligned}
& u(x)=\frac{x-\text { Low }}{\text { High }- \text { Low }} \\
& \text { where } \\
& \qquad \begin{array}{l}
\text { Low } \quad=0, \text { lower than sea-level rise } \\
\text { High } \quad=1 \text {, above sea-level rise }
\end{array}
\end{aligned}
$$

Figure 2.9. Change in marsh surface elevation relative to sea-level rise at the Chincoteague National Wildlife Refuge, Virginia.

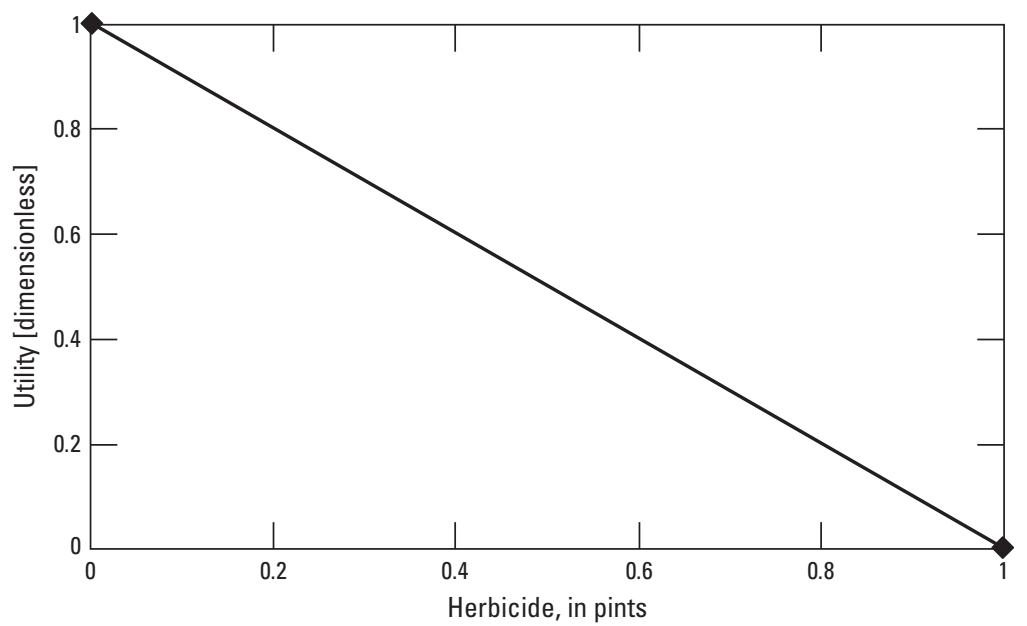

$$
\begin{aligned}
& u(x)=\frac{\text { High }-x}{\text { High }- \text { Low }} \\
& \text { where } \\
& \qquad \begin{array}{c}
\text { Low }=0 \\
\text { High }=1
\end{array}
\end{aligned}
$$

Figure 2.10. Application of herbicides at the Chincoteague National Wildlife Refuge, Virginia. 

For more information, contact: U.S. Geological Survey

Director, Patuxent Wildlife Research Center 12100 Beech Forest Road

Laurel, MD 20708-4039

https://www.usgs.gov/centers/pwrc

Publishing support provided by the

Pembroke and Tacoma Publishing Service Centers 
急

$\frac{\overrightarrow{0}}{0}$

을

. 